\title{
Global prediction of planktic foraminiferal fluxes from hydrographic and productivity data
}

\author{
S. Žarić, M. Schulz, and S. Mulitza \\ DFG Research Center Ocean Margins, University of Bremen, P.O. Box 330440, 28334 Bremen, Germany
}

Received: 13 June 2005 - Published in Biogeosciences Discuss.: 22 July 2005

Revised: 8 February 2006 - Accepted: 22 February 2006 - Published: 4 May 2006

\begin{abstract}
Understanding and quantifying the seasonal and spatial distribution of planktic foraminiferal fluxes reflected in sedimentary assemblages is key to interpret foraminiferabased proxies in paleoceanography. Towards this goal we present an empirical model to predict foraminiferal fluxes on a global scale.

A compilation of planktic foraminiferal flux and export production data from globally distributed sediment traps together with environmental data of sea-surface temperature and mixed-layer depth from online databases is used to calibrate the model that calculates monthly foraminiferal fluxes for the 18 most common species. The calibrated model is then forced with a global data set of hydrographic and productivity data to predict monthly foraminiferal fluxes worldwide. The predictive skills of the model are assessed by comparing the model output with planktic foraminiferal assemblages from globally distributed surface sediments as well as with measured foraminiferal fluxes of sediment traps not included in the calibration data set.

Many general distribution patterns of foraminiferal species recognized from the model output compare favorably with observations from coretops or sediment traps, even though the model still produces problematic results in some places. Among others, meridional gradients in species richness and diversity, increased relative abundances of Neogloboquadrina pachyderma (dex.) in upwelling areas, and peak abundances of Globigerinella siphonifera in oligotrophic subtropical gyres show good agreement between model and coretops. Absolute foraminiferal fluxes are significantly underestimated in most cases, while seasonal variations can be reproduced for some species. Interannual differences in foraminiferal fluxes are not reflected by the model which might partly be due to a lack of actual environmental data for the calibration and model experiments.
\end{abstract}

Correspondence to: S. Žarić

(zaric@uni-bremen.de)
The limited predictive skills of the model suggest that additional parameters should be considered. Export production should probably be replaced by a more realistic representation of food availability for planktic foraminifera. This could be achieved by adding a dynamic component to the model and linking it to an ecosystem model.

\section{Introduction}

The shell chemistry as well as the assemblage composition of planktic foraminifera are among the most important proxies used in paleoceanography (e.g. Wefer et al., 1999). However, there is often a significant seasonal bias in foraminiferal species fluxes to the seafloor, which is crucial for paleoceanographic interpretations of the proxy data (e.g. Deuser and Ross, 1989; Wefer, 1989; Mulitza et al., 1998; Ganssen and Kroon, 2000; King and Howard, 2001; Pflaumann et al., 2003; Waelbroeck et al., 2005). For example, Niebler et al. (2003) suggested, that discrepancies in temperature reconstructions applying foraminifera- versus alkenone-based proxies might be due to different ecological and thus seasonal preferences of the shell producers.

Seasonal variations in foraminiferal fluxes are strongly influenced by the different species sensitivities to environmental parameters: Numerous studies on plankton-tow and sediment-trap material as well as on laboratory cultures and surface sediments have shown, that sea-surface temperature (SST), the thermal structure of the water column and food supply among others can have a considerable effect on fluxes and relative abundances of foraminiferal species (e.g. Bijma et al., 1990b; Ortiz et al., 1995; Watkins et al., 1996; Watkins and Mix, 1998; Eguchi et al., 1999; Schiebel et al., 2001; King and Howard, 2003a; Morey et al., 2005; Žarić et al., 2005, and references in Table 1).

Sediment traps are a useful tool in these investigations, as they can resolve seasonal and interannual differences in

Published by Copernicus GmbH on behalf of the European Geosciences Union. 
particle flux (e.g. Deuser, 1986; Fischer and Wefer, 1996; Kincaid et al., 2000). Because of the relatively large size and weight of planktic foraminifera, their shells usually reach the traps within days and mostly without significant lateral displacement (e.g. Takahashi and Bé, 1984). Hence, trap data can be directly related to modern surface hydrography (e.g. Tedesco and Thunell, 2003; Marchant et al., 2004; Mohiuddin et al., 2004; Žarić et al., 2005).

To minimize errors in the application of foraminiferabased proxies it is of great importance to thoroughly understand the seasonal and spatial distribution of foraminiferal fluxes reflected in sedimentary assemblages and to be able to quantify it on a global scale.

Here, we present, to our knowledge, the first attempt to globally predict foraminiferal fluxes at species level (18 most common species) depending on the environmental parameters sea-surface temperature, mixed-layer depth (MLD) and export production in $1000 \mathrm{~m}$ water depth (PEX). The empirical model is calibrated by a compilation of planktic foraminiferal flux and PEX data from globally distributed sediment traps in combination with environmental data of SST and MLD from online databases. We force the calibrated model with a global data set of hydrographic and productivity data to calculate monthly foraminiferal fluxes on a global scale. We then compare modeled annual relative species abundances with coretop-derived foraminiferal assemblage data. Finally, we test the model by comparing predicted and measured foraminiferal fluxes at trap positions not included in the calibration.

Our study shows that the empirical model is able to reproduce many general distribution patterns of planktic foraminiferal assemblages observed in the world's oceans like diversity patterns or relative abundance distributions of some species, even though it cannot reliably predict absolute monthly foraminiferal fluxes yet.

\section{Material and methods}

\subsection{Calibration data set}

To calibrate our model we used a global data set compiled by Žarić et al. (2005). This database contains planktic foraminiferal fluxes calculated from various sediment-trap investigations, actual SSTs taken from the IGOSS database (Reynolds and Smith, 1994) (http://iridl.ldeo.columbia.edu/ SOURCES/.IGOSS/.nmc/) as well as export production data, which have been derived from organic carbon fluxes measured with the same traps. To account for remineralization during descent, the organic carbon fluxes have been normalized to an average trap depth of $1000 \mathrm{~m}$ by applying the power function proposed by Martin et al. (1987) with correction after Francois et al. (2002; Eq. 14 therein). Even though this can only be a first approximation (Žarić et al., 2005), we decided to still use export production, because it was the only productivity-related parameter being available in the temporal resolution of sediment trap samples.

We extended the database of Žarić et al. (2005) by adding several North Atlantic traps (Jensen, 1998; Peinert et al., 2000; Schröder-Ritzrau et al., 2000; Antia et al., 2001; Schiebel, 2002) complementing SST and PEX data for every sample as described by Žarić et al. (2005). Furthermore we added information on the depths of the mixed layer. These were calculated from monthly temperature and salinity data obtained from the World Ocean Atlas 2001 (WOA 2001; Conkright et al., 2002) (http://www.nodc.noaa.gov/ OC5/WOA01/) based on a constant density difference criterion of 0.125 sigma units between ocean surface and base of the mixed layer. In polar regions, where deep mixing occurs, a density difference of $10^{-5}$ sigma units was used. The minimum mixed-layer depth was set to $25 \mathrm{~m}$. The same value was used for sea-ice covered regions. Data from the $1 \times 1^{\circ}$ grid-points closest to each sediment trap position were transformed to weekly values, and mean mixed-layer depths were calculated for every sampling interval. We applied the same time-lag between trap data and surface hydrography as described by Žarić et al. (2005): Due to life cycles of foraminifera an adjustment of two weeks was used for all sediment-trap data (Sautter and Thunell, 1991). An additional one-week correction (i.e. 3 weeks in total) was used for traps deeper than $1750 \mathrm{~m}$ water depth to account for foraminiferal settling through the water column, which translates into assumed average sinking velocities of $500 \mathrm{~m}$ per day (Takahashi and Bé, 1984). Furthermore, where only fluxes of all occurring species were given, we set fluxes of the remaining species to zero ("void observations"). If no information was available on the organic carbon flux or if the total foraminiferal flux was zero, the sample was excluded from further investigation. Altogether the calibration data set consists of 1327 samples. Table 1 summarizes locations, details and references of the sediment trap studies included in our model calibration.

\subsection{Statistical analysis and model development}

Foraminiferal flux data of the following 18 species were examined in our study: Globigerina bulloides, Globigerinella calida, G. siphonifera, Globigerinita glutinata, Globigerinoides ruber (white and pink varieties), G. sacculifer, Globorotalia inflata, G. menardii, G. scitula, G. truncatulinoides, Globoturborotalita rubescens, Neogloboquadrina dutertrei, $N$. pachyderma (sinistral and dextral coiling varieties), Orbulina universa, Pulleniatina obliquiloculata and Turborotalita quinqueloba. Each of these species was present in at least $15 \%$ of the samples. Other species account for only $5.6 \%$ of the foraminiferal assemblage on an average.

The empirical model is based on a multiple linear regression approach. As there is no linear relationship between most foraminiferal fluxes and environmental parameters, we applied the ACE algorithm prior to regression to estimate 
Table 1. Locations, trap and water depths, sieve size and data sources of the planktic foraminiferal faunas included in the calibration data set.

\begin{tabular}{|c|c|c|c|c|c|c|c|}
\hline Trap Location & & $\begin{array}{l}\text { Latitude } \\
{\left[{ }^{\circ} \mathrm{N}\right]}\end{array}$ & $\begin{array}{l}\text { Longitude } \\
\quad\left[{ }^{\circ} \mathrm{E}\right]\end{array}$ & $\begin{array}{l}\text { Trap Depths } \\
{[\mathrm{m}]}\end{array}$ & $\begin{array}{l}\text { Water Depth } \\
\text { [m] }\end{array}$ & $\begin{array}{l}\text { Sieve } \\
\text { Size } \\
{[\mu \mathrm{m}]}\end{array}$ & References \\
\hline Ocean Station Papa & & 50.00 & -145.00 & 3800 & 4240 & $>125$ & $\begin{array}{l}\text { Reynolds and Thunell (1985, 1986); } \\
\text { Sautter and Thunell (1989); } \\
\text { Wong et al. (1999) }\end{array}$ \\
\hline California Current & $\begin{array}{l}\text { NS } \\
\text { MW } \\
\text { G }\end{array}$ & $\begin{array}{l}42.09 \\
42.19 \\
41.54\end{array}$ & $\begin{array}{l}-125.77 \\
-127.58 \\
-132.02\end{array}$ & $\begin{array}{l}1000 \\
1000 \\
1000\end{array}$ & $\begin{array}{l}2829 \\
2830 \\
3664\end{array}$ & $\begin{array}{l}>150 \\
>150 \\
>150\end{array}$ & Ortiz and Mix (1992); Lyle et al. (1992) \\
\hline Peru-Chile Current $^{\mathrm{a}}$ & & -30.01 & -73.18 & 2318 & 4345 & $>150$ & $\begin{array}{l}\text { Marchant et al. (1998); Hebbeln et al. } \\
(2000)\end{array}$ \\
\hline N' North Atlantic & $\begin{array}{l}\mathrm{OG} \\
\mathrm{NB}\end{array}$ & $\begin{array}{l}72.38 \\
69.69\end{array}$ & $\begin{array}{c}-7.71 \\
0.48\end{array}$ & $\begin{array}{l}500 ; 1000 ; 2300 \\
500 ; 1000\end{array}$ & $\begin{array}{l}2624 \\
3254\end{array}$ & $\begin{array}{l}>125 \\
>125\end{array}$ & Jensen (1998); Peinert et al. (2000) \\
\hline North Atlantic & $\begin{array}{l}\mathrm{L}^{\mathrm{a}} \\
\mathrm{L} 3\end{array}$ & $\begin{array}{l}47.78 \\
54.66\end{array}$ & $\begin{array}{l}-19.78 \\
-21.23\end{array}$ & $\begin{array}{l}1015 ; 2015 ; 3515 \\
2200\end{array}$ & $\begin{array}{l}5483 \\
5370\end{array}$ & $\begin{array}{l}>150 \\
>150\end{array}$ & Schiebel (2002); Antia et al. (2001) \\
\hline Sargasso Sea & & 32.08 & -64.25 & 3200 & 4200 & $>125$ & $\begin{array}{l}\text { Deuser et al. (1981); Deuser (1987); } \\
\text { Deuser and Ross (1989) }\end{array}$ \\
\hline Canary Islands & $\begin{array}{l}\text { LP } \\
\text { CI } \\
\text { EBC }\end{array}$ & $\begin{array}{l}29.76 \\
29.18 \\
28.71\end{array}$ & $\begin{array}{l}-17.95 \\
-15.45 \\
-13.16\end{array}$ & $\begin{array}{c}900 \\
500 ; 750 \\
700\end{array}$ & $\begin{array}{c}4327 \\
3610 \\
996\end{array}$ & $\begin{array}{l}>125 \\
>125 \\
>125\end{array}$ & $\begin{array}{l}\text { Freudenthal et al. (2001); } \\
\text { Abrantes et al. (2002); } \\
\text { Wilke et al. }(2005)^{1}\end{array}$ \\
\hline Cape Blanc & $\begin{array}{l}1 \\
2-5^{\mathrm{a}}\end{array}$ & $\begin{array}{l}20.76 \\
21.15\end{array}$ & $\begin{array}{l}-19.74 \\
-20.68\end{array}$ & $\begin{array}{c}2195 \\
732 ; 3552\end{array}$ & $\begin{array}{l}3646 \\
4103\end{array}$ & $\begin{array}{l}>150 \\
>150\end{array}$ & $\begin{array}{l}\text { Fischer and Wefer (1996); } \\
\text { Fischer et al. (1996); Žarić et al. (2005) }\end{array}$ \\
\hline W Equatorial Atlantic & $\begin{array}{l}1 \\
2-3^{\mathrm{a}}\end{array}$ & $\begin{array}{l}-4.00 \\
-7.52\end{array}$ & $\begin{array}{l}-25.57 \\
-28.04\end{array}$ & $\begin{array}{l}652 ; 1232 ; 4991 \\
631 ; 5031\end{array}$ & $\begin{array}{l}5530 \\
5570\end{array}$ & $\begin{array}{l}>150 \\
>150\end{array}$ & $\begin{array}{l}\text { Fischer and Wefer (1996), } \\
\text { Fischer (unpubl. data); Žarić et al. (2005) }\end{array}$ \\
\hline W Atlantic & $\mathrm{WAB}^{\mathrm{a}}$ & -11.57 & -28.53 & $719 ; 4515$ & 5472 & $>150$ & Fischer (unpubl. data); Žarić et al. (2005) \\
\hline E Equatorial Atlantic & $\begin{array}{l}1 \\
2 \\
3 \\
4\end{array}$ & $\begin{array}{c}3.17 \\
1.78 \\
-0.08 \\
-2.19\end{array}$ & $\begin{array}{l}-11.25 \\
-11.25 \\
-10.77 \\
-10.09\end{array}$ & $\begin{array}{c}984 \\
953 \\
1097 \\
1068\end{array}$ & $\begin{array}{l}4524 \\
4399 \\
4141 \\
3906\end{array}$ & $\begin{array}{l}>150 \\
>150 \\
>150 \\
>150\end{array}$ & $\begin{array}{l}\text { Fischer and Wefer (1996); } \\
\text { Žarić et al. (2005) }\end{array}$ \\
\hline Walvis Ridge & $\begin{array}{l}2-3 \\
4\end{array}$ & $\begin{array}{l}-20.05 \\
-20.13\end{array}$ & $\begin{array}{l}9.16 \\
8.96\end{array}$ & $\begin{array}{c}599 ; 1648 \\
1717\end{array}$ & $\begin{array}{l}2202 \\
2263\end{array}$ & $\begin{array}{l}>150 \\
>150\end{array}$ & $\begin{array}{l}\text { Fischer and Wefer (1996); } \\
\text { Žarić et al. (2005) }\end{array}$ \\
\hline Weddell Sea & $\begin{array}{l}1 \\
2-4^{\mathrm{a}}\end{array}$ & $\begin{array}{l}-62.44 \\
-64.91\end{array}$ & $\begin{array}{l}-34.76 \\
-2.55\end{array}$ & $\begin{array}{c}863 \\
356 ; 4456\end{array}$ & $\begin{array}{l}3880 \\
5032\end{array}$ & $\begin{array}{l}>125 \\
>125\end{array}$ & Donner and Wefer (1994) \\
\hline Arabian Sea & $\begin{array}{l}\text { WAST }^{\mathrm{a}} \\
\text { CAST }^{\mathrm{a}} \\
\text { EAST }^{\mathrm{a}}\end{array}$ & $\begin{array}{l}16.33 \\
14.49 \\
15.48\end{array}$ & $\begin{array}{l}60.49 \\
64.76 \\
68.74\end{array}$ & $\begin{array}{l}3026 \\
2909 \\
2775\end{array}$ & $\begin{array}{l}4016 \\
3901 \\
3774\end{array}$ & $\begin{array}{l}>150 \\
>150 \\
>150\end{array}$ & $\begin{array}{l}\text { Curry et al. (1992); } \\
\text { Guptha and Mohan (1996); } \\
\text { Haake et al. (1993) }\end{array}$ \\
\hline Bay of Bengal & $\begin{array}{l}\text { NBBT } \\
\text { CBBT } \\
\text { SBBT }^{\mathrm{b}}\end{array}$ & $\begin{array}{c}17.45 \\
13.15 \\
5.00\end{array}$ & $\begin{array}{l}89.60 \\
84.35 \\
87.05\end{array}$ & $\begin{array}{c}967 ; 1498 ; 2029 \\
950 ; 2286 \\
1518\end{array}$ & $\begin{array}{l}2263 \\
3259 \\
4017\end{array}$ & $\begin{array}{l}>150 \\
>150 \\
>125\end{array}$ & $\begin{array}{l}\text { Guptha and Mohan (1996); } \\
\text { Guptha et al. (1997); } \\
\text { Unger et al. (2003) }\end{array}$ \\
\hline NW' Pacific & $\begin{array}{l}\text { WCT- } 1^{\mathrm{a}} \\
\text { WCT- }^{\mathrm{a}}\end{array}$ & $\begin{array}{l}25.00 \\
39.01\end{array}$ & $\begin{array}{l}136.99 \\
147.00\end{array}$ & $\begin{array}{c}917 ; 1388 ; 4336 ; 4758 \\
1371 ; 1586 ; 4787\end{array}$ & $\begin{array}{l}5107 \\
5339\end{array}$ & $\begin{array}{l}>125 \\
>125\end{array}$ & Mohiuddin et al. (2002) \\
\hline NW' North Pacific & $\begin{array}{l}50 \mathrm{~N} \\
\text { KNOT } \\
40 \mathrm{~N}\end{array}$ & $\begin{array}{l}50.02 \\
43.97 \\
40.00\end{array}$ & $\begin{array}{l}165.03 \\
155.05 \\
165.00\end{array}$ & $\begin{array}{l}3260 \\
2957 \\
2986\end{array}$ & $\begin{array}{l}5570 \\
5370 \\
5483\end{array}$ & $\begin{array}{l}>125 \\
>125 \\
>125\end{array}$ & Kuroyanagi et al. (2002) \\
\hline Subantarctic Zone & $\begin{array}{l}\text { SAZ } 47 \\
\text { SAZ } 51 \\
\text { SAZ } 54\end{array}$ & $\begin{array}{l}-46.76 \\
-51.00 \\
-53.75\end{array}$ & $\begin{array}{l}142.07 \\
141.74 \\
141.76\end{array}$ & $\begin{array}{c}1060 ; 3850 \\
3080 \\
830 ; 1580\end{array}$ & $\begin{array}{l}4540 \\
3780 \\
2280\end{array}$ & $\begin{array}{l}>150 \\
>150 \\
>150\end{array}$ & $\begin{array}{l}\text { King and Howard }(2003 a, b) \text {; } \\
\text { Trull et al. (2001) }\end{array}$ \\
\hline Chatham Rise & $\begin{array}{l}\text { NCR } \\
\text { SCR }\end{array}$ & $\begin{array}{l}-42.70 \\
-44.62\end{array}$ & $\begin{array}{l}178.63 \\
178.62\end{array}$ & $\begin{array}{l}300 ; 1000 \\
300 ; 1000\end{array}$ & $\begin{array}{l}1500 \\
1500\end{array}$ & $\begin{array}{l}>150 \\
>150\end{array}$ & $\begin{array}{l}\text { King and Howard (2001); } \\
\text { Nodder and Northcote (2001) }\end{array}$ \\
\hline
\end{tabular}

a Position and/or depths averaged over more than one collection period

${ }^{\mathrm{b}}$ Flux data available for $G$. bulloides only 


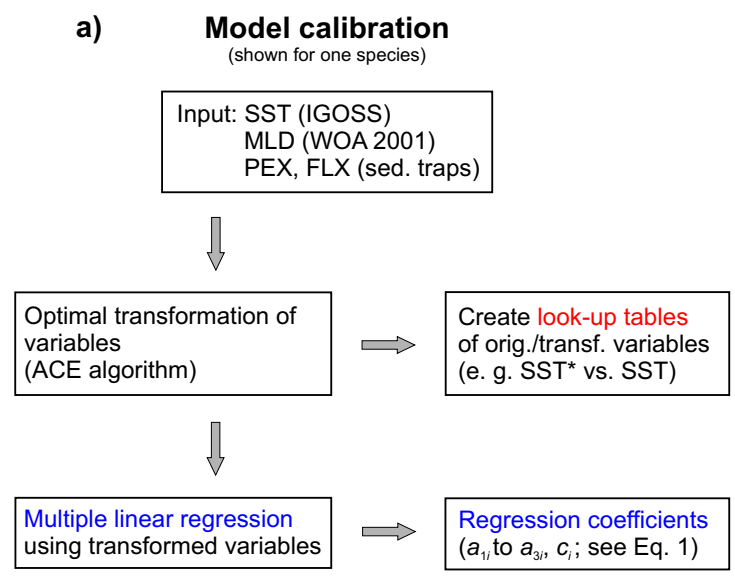

\section{b) Global model experiment}

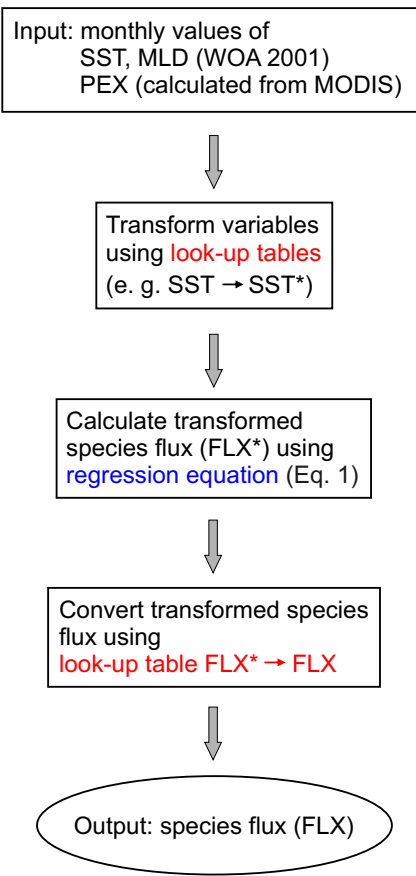

Fig. 1. Schematic summary of (a) the model calibration and (b) the global model experiment. SST = sea-surface temperature, MLD = mixed-layer depth, PEX = export production in $1000 \mathrm{~m}$ water depth, FLX = flux of a foraminiferal species. Note that actual SST data from the time of trap deployment were used for the calibration in (a), because these are more accurate when related to trap data. On the other hand, the global model experiment in (b) was forced with long-term monthly mean values of SST in order to better compare the model results to coretop samples. For further explanation, see text.

optimal transformations for multiple regression and correlation (Breiman and Friedman, 1985). The algorithm transforms each variable such, that multiple linear regression of the transformed variables (denoted by an asterisk) yields the highest coefficients of determination $\left(r^{2}\right)$. For the statistical analysis being the basis of the model calibration we treated SST, MLD and PEX as predictor variables and the flux of the respective foraminiferal species (FLX) as the dependent variable:

$\mathrm{FLX}_{i}^{*}=a_{1 i} \mathrm{SST}^{*}+a_{2 i} \mathrm{MLD}^{*}+a_{3 i} \mathrm{PEX}^{*}+c_{i}$.

Here $\mathrm{SST}^{*}, \mathrm{MLD}^{*}$ and $\mathrm{PEX}^{*}$ are transformed values of seasurface temperature, mixed-layer depth, and export production in $1000 \mathrm{~m}$ water depth, respectively. FLX ${ }_{i}^{*}$ is the transformed flux of species $i(i=1, \ldots, 18), a_{1 i}$ to $a_{3 i}$ are speciesdependent regression coefficients and $c_{i}$ a regression constant. It should be mentioned, that since the environmental parameters can be partially intercorrelated, multicolinearity may have an effect on the statistical analysis.

Look-up tables were derived from the ACE output to be used for variable transformations within the model $\left(\mathrm{SST} \rightarrow \mathrm{SST}^{*}, \mathrm{MLD} \rightarrow \mathrm{MLD}^{*}, \mathrm{PEX} \rightarrow \mathrm{PEX}^{*}\right)$ and regression parameters were estimated (see Fig. 1a). The calculated transformed species flux from Eq. (1) is back-transformed
$\left(\mathrm{FLX}^{*} \rightarrow\right.$ FLX) to obtain a flux in units of [ind. $\mathrm{m}^{-2} \mathrm{~d}^{-1}$ ]. The inverse transformation necessitates that the transformation of species fluxes with the ACE algorithm is forced to behave strongly monotonic, so that each transformed flux corresponds to a single untransformed value. Planktic foraminiferal species were analyzed separately on the dependence of their fluxes on the mentioned environmental parameters. For every analysis only those samples from the compilation were included, where all variables were available. Hence, the number of samples varied for every single species under consideration.

In total, the foraminiferal flux model comprises 54 lookup tables that allow for a transformation of the three environmental input parameters SST, MLD and PEX for each of the 18 species considered. Furthermore, it contains 18 look-up tables that permit back-transformation into single foraminiferal species fluxes. By forcing the model with a data set of the environmental input parameters, planktic foraminiferal species fluxes are calculated separately and these are additionally converted to percentages of the modeled foraminiferal assemblage. G. ruber (pink) is only calculated for the Atlantic Ocean, since it became extinct in the Indo-Pacific at $128000 \mathrm{yr}$ BP (Ivanova et al., 2003, see also Thompson et al., 1979). According to the SST ranges of the 
Table 2. Locations, trap and water depths, sieve size and data sources of the planktic foraminiferal faunas not included in the calibration data set. These were used to compare the seasonal signal of measured and modeled foraminiferal fluxes.

\begin{tabular}{|c|c|c|c|c|c|c|c|}
\hline Trap Location & & $\begin{array}{l}\text { Latitude } \\
{\left[{ }^{\circ} \mathrm{N}\right]}\end{array}$ & $\begin{array}{l}\text { Longitude } \\
{\left[{ }^{\circ} \mathrm{E}\right]}\end{array}$ & $\begin{array}{l}\text { Trap Depths } \\
{[\mathrm{m}]}\end{array}$ & $\begin{array}{l}\text { Water Depth } \\
{[\mathrm{m}]}\end{array}$ & $\begin{array}{c}\text { Sieve } \\
\text { Size } \\
{[\mu \mathrm{m}]}\end{array}$ & References \\
\hline San Pedro Basin & & 33.55 & -118.50 & 500 & 880 & $>125$ & Sautter and Thunell (1991) \\
\hline Greenland Sea & & 75.00 & 0.00 & $300 ; 900$ & 3720 & $>125$ & Jensen (1998) \\
\hline Cariaco Basin & & 10.50 & -64.67 & 275 & 1400 & $>125$ & Tedesco and Thunell (2003) \\
\hline \multirow[t]{2}{*}{ Benguela Upwelling } & WB1 & -23.03 & 12.44 & 968 & 1803 & $>150$ & Žarić et al. (2005) \\
\hline & Benguela & -23.00 & 12.98 & 545 & 595 & $>125$ & Giraudeau et al. (2000) \\
\hline \multirow[t]{3}{*}{ Arabian Sea } & MST8-B & 10.76 & 51.94 & 1265 & 1533 & $>150$ & $\begin{array}{l}\text { Conan and Brummer (2000); } \\
\text { Conan et al. (2002) }\end{array}$ \\
\hline & $\begin{array}{l}\text { WAST }^{\mathrm{a}} \\
\text { CAST }^{\mathrm{a}} \\
\text { EAST }^{\mathrm{a}}\end{array}$ & $\begin{array}{l}16.31 \\
14.49 \\
15.48\end{array}$ & $\begin{array}{l}60.47 \\
64.76 \\
68.74\end{array}$ & $\begin{array}{c}1028 \\
733 \\
1401\end{array}$ & $\begin{array}{l}4014 \\
3901 \\
3776\end{array}$ & $\begin{array}{l}>150 \\
>150 \\
>150\end{array}$ & Curry et al. (1992) \\
\hline & $\mathrm{SAST}^{\mathrm{b}}$ & 13.13 & 67.12 & 1654 & 4075 & $>125$ & Guptha and Mohan (1996) \\
\hline Subantarctic Zone & SAZ 47 & -46.76 & 142.07 & 3850 & 4540 & $>150$ & King and Howard $(2003 a, b)$ \\
\hline
\end{tabular}

a Position and depths averaged over more than one collection period

${ }^{\mathrm{b}}$ Flux data available for $G$. bulloides only

individual species, which were derived as outlined in Žarić et al. (2005), cutoffs were defined to assure that species are not calculated out of their present-day SST range (Appendix A, Table A1).

\subsection{Global model run}

For a global model run the foraminiferal flux model was forced with a global monthly data set of SST, MLD and PEX $\left(1 \times 1^{\circ}\right.$ grid). SST data were obtained from the World Ocean Atlas 2001 (Conkright et al., 2002), the MLD was calculated as described above. PEX was calculated from satellitederived primary production data obtained from the Goddard Earth Sciences Data and Information Services Center Distributed Active Archive Center. We used Moderate Resolution Imaging Spectroradiometer (MODIS) data available as 8-day composites (http://daac.gsfc.nasa.gov/MODIS/Terra/ ocean/MOAPW1.shtml) and calculated monthly means for the time interval December 2002 to November 2003. To estimate export production in $1000 \mathrm{~m}$ water depth (PEX) the following equation was applied (Antia et al., 2001):

$F_{\text {Corg }}=0.1 \mathrm{PP}^{1.77} z^{-0.68}$

where $F_{\text {Corg }}$ is the organic carbon flux $\left(\mathrm{g} \mathrm{C} \mathrm{m}^{-2} \mathrm{yr}^{-1}\right)$ at depth $z(\mathrm{~m})$ and PP is primary production $\left(\mathrm{g} \mathrm{C} \mathrm{m}^{-2} \mathrm{yr}^{-1}\right)$. Using Eq. (2) should be considered as a first approximation, since the equation is based on annually averaged fluxes, but export ratios vary on shorter timescales due to seasonally changing productivity patterns (Antia, personal communication).

Calculated monthly fluxes for the 18 foraminiferal species considered (see Fig. 1b) were annually averaged and also converted into relative abundances to allow for a comparison of the model results with coretop foraminiferal fauna data. This implies that months with missing flux calculations due to missing PEX data do not yield any foraminiferal fluxes. Species fluxes were summed to assess total foraminiferal fluxes (note that "total" here means only the sum of the species included in the model). For the global model output we determined species richness as the number of species present. In addition, species diversity $(H)$, which takes into account the relative abundance $p_{i}$ of each species, was also determined after Shannon and Weaver (1949):

$H=-\sum p_{i} \ln \left(p_{i}\right)$

$H$ increases with increasing species richness and with more evenly distributed relative abundances of the species. For a better comparison between the ocean basins, we combined the pink and white varieties of $G$. ruber when calculating species richness and diversity, since G. ruber (pink) occurs only in the Atlantic Ocean.

Maps illustrating our results were generated using the software Ocean Data View (Schlitzer, 2002a). 
Table 3. Adjusted coefficients of determination $\left(r^{2}\right)$ and standardized regression coefficients of the multiple linear regressions between the transformed variables SST*, MLD*, $\mathrm{PEX}^{*}$ and $\mathrm{FLX}^{*}$ for the 18 species included in the model.

\begin{tabular}{|c|c|c|c|c|}
\hline Species & Adj. $r^{2}$ & $\begin{array}{c}\mathrm{SST}^{*} \\
\beta_{1}\end{array}$ & $\begin{array}{c}\mathrm{MLD}^{*} \\
\beta_{2}\end{array}$ & $\begin{array}{c}\mathrm{PEX}^{*} \\
\beta_{3}\end{array}$ \\
\hline G. bulloides & 0.500 & 0.419 & 0.175 & 0.452 \\
\hline G. calida & 0.400 & 0.494 & 0.243 & 0.196 \\
\hline G. siphonifera & 0.538 & 0.723 & 0.162 & 0.091 \\
\hline G. glutinata & 0.352 & 0.316 & 0.208 & 0.397 \\
\hline G. ruber (pink) & 0.537 & 0.547 & 0.372 & 0.226 \\
\hline G. ruber (white) & 0.696 & 0.836 & 0.117 & 0.188 \\
\hline G. sacculifer & 0.541 & 0.676 & 0.154 & 0.195 \\
\hline G. inflata & 0.443 & 0.534 & 0.307 & 0.239 \\
\hline G. menardii & 0.419 & 0.563 & 0.210 & 0.309 \\
\hline G. scitula & 0.425 & 0.522 & 0.269 & 0.189 \\
\hline G. truncatulinoides & 0.337 & 0.338 & 0.394 & 0.083 \\
\hline G. rubescens & 0.290 & 0.463 & 0.289 & 0.077 \\
\hline N. dutertrei & 0.445 & 0.457 & 0.191 & 0.399 \\
\hline N. pachyderma (dex.) & 0.750 & 0.772 & 0.144 & 0.253 \\
\hline N. pachyderma $(\sin )$. & 0.728 & 0.946 & 0.233 & 0.071 \\
\hline O. universa & 0.326 & 0.439 & 0.197 & 0.174 \\
\hline P. obliquiloculata & 0.298 & 0.519 & 0.252 & 0.200 \\
\hline T. quinqueloba & 0.685 & 0.808 & 0.193 & 0.099 \\
\hline
\end{tabular}

Highest $\beta$-value for each species is marked bold

\subsection{Comparison to coretop data}

To compare our model results with an independent data set we used the Brown University Foraminiferal Database (Prell et al., 1999) (ftp://ftp.ngdc.noaa.gov/paleo/paleocean/ brown_foram/). This data set contains foraminifera counts of 1265 globally distributed coretop samples. We calculated relative abundances of the species, species richness and the Shannon diversity index by considering only the 18 species included in our model.

2.5 Comparison to sediment trap data not included in the calibration

Several sediment trap data have not been included in the calibration data set because they were lacking the organic carbon flux data and hence were incomplete. These data (for details and references see Table 2) were used to compare measured with modeled foraminiferal fluxes. To account at least in part for interannual differences in environmental parameters, the model was forced with monthly SST data covering the time of sediment-trap deployment that were obtained from the IGOSS database (Reynolds and Smith, 1994) instead of using long-term monthly means from the World Ocean Atlas 2001 (Conkright et al., 2002).

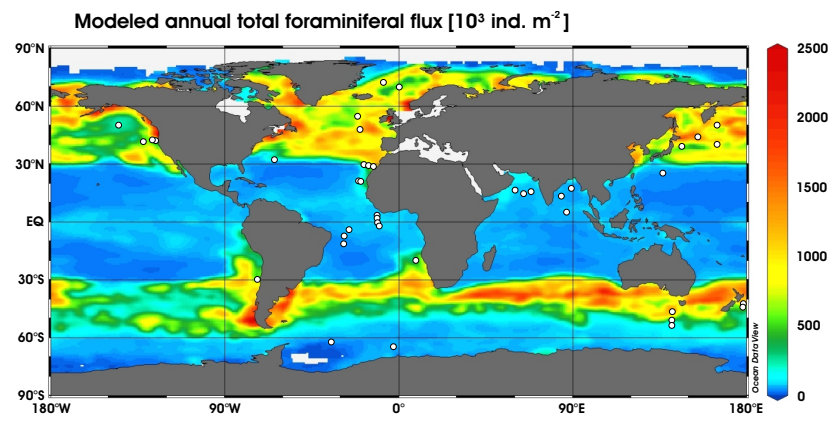

Fig. 2. Modeled annual total foraminiferal flux $\left[10^{3}\right.$ ind. $\left.\mathrm{m}^{-2}\right]$ of the 18 species included in the model, circles mark positions of sediment traps comprised in the calibration data set (see Table 1).

\section{Results}

\subsection{Statistical analysis}

Table 3 shows the results of the multiple linear regressions of the transformed variables conducted for every species. Adjusted $r^{2}$ values lie between 0.29 for G. rubescens and 0.75 for $N$. pachyderma (dex.), indicating that variations in SST, MLD and PEX explain between $\sim 30$ to $75 \%$ of the recorded foraminiferal fluxes. The standardized regression coefficients reflect the significant influence of SST on most of the species, especially on G. siphonifera, G. ruber (white), G. sacculifer, N. pachyderma (dex. and sin.) and T. quinqueloba. Export production seems to play an important role primarily for G. bulloides, G. glutinata, G. menardii and $N$. dutertrei, while regression coefficients for the MLD are highest for G. ruber (pink), G. inflata and G. truncatulinoides.

\subsection{Annual species abundances - global model experiment} vs. coretops

The modeled annual total foraminiferal flux is shown in Fig. 2. Low fluxes were calculated across the tropics and in polar regions. A wide band of high foraminiferal fluxes can be seen in the northern hemisphere $\left(>30^{\circ} \mathrm{N}\right)$, a comparably narrow band of highest fluxes in the Southern Ocean (predominantly between $30-45^{\circ} \mathrm{S}$ ). Increased planktic foraminiferal fluxes were also predicted within the major Eastern Boundary Currents.

Figure 3 illustrates species richness calculated from the global model output as compared to the richness monitored in surface sediments. The general trend of highest species richness at mid-latitudes and decreasing values towards higher latitudes predicted by the model is also reflected in foraminiferal assemblages of coretops. In addition the model reproduces higher species richness in low latitudes of the eastern Atlantic compared to the western part as observed in surface sediments. Furthermore, the distribution pattern of species diversities $H$ calculated for the model 

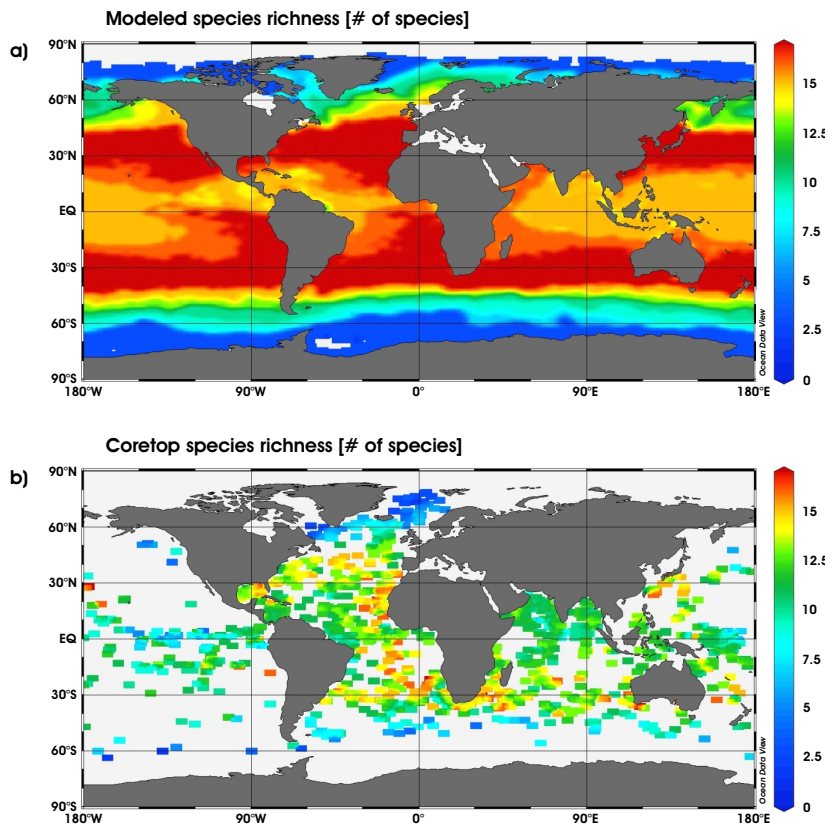

Fig. 3. Species richness [\# of species] calculated from (a) the model and (b) coretop foraminiferal assemblages (Prell et al., 1999) considering only species included in the model. White and pink G. ruber are combined.

output after Shannon and Weaver (1949) resembles coretop diversity patterns (Fig. 4). In general, species diversities are distinctly lower in high latitudes and show maximum values in rather narrow bands at mid-latitudes in surface sediments and model results. A shift of high diversities to lower latitudes detected in eastern Atlantic coretop samples is predicted by the model as well.

The comparison of modeled annual relative abundances of individual species with their abundances in surface sediments revealed that the global abundance patterns of some species match favorably well with their seafloor record while others are not properly reproduced. For example, Figs. 5-8 show modeled and coretop relative abundances of the four species N. pachyderma (sin.), N. pachyderma (dex.), G. bulloides and G. siphonifera, respectively, which were among the species better predicted in the model. Coretop as well as modeled assemblages yield highest abundances of the coldwater species $N$. pachyderma (sin.) in polar waters. Modeled N. pachyderma (dex.) shows increased contribution to the foraminiferal assemblage around $40^{\circ} \mathrm{N} / \mathrm{S}$, following the Gulf Stream into the northeastern N-Atlantic and being present in significant amounts in the major upwelling areas along the Eastern Boundary Currents, just as recorded by surface sediments. Peak abundances of G. bulloides are modeled at mid-latitudes which is mirrored by coretops as well. However, relative abundances are being significantly overestimated in the N-Atlantic and underestimated in highly productive upwelling areas like the western Arabian Sea or off
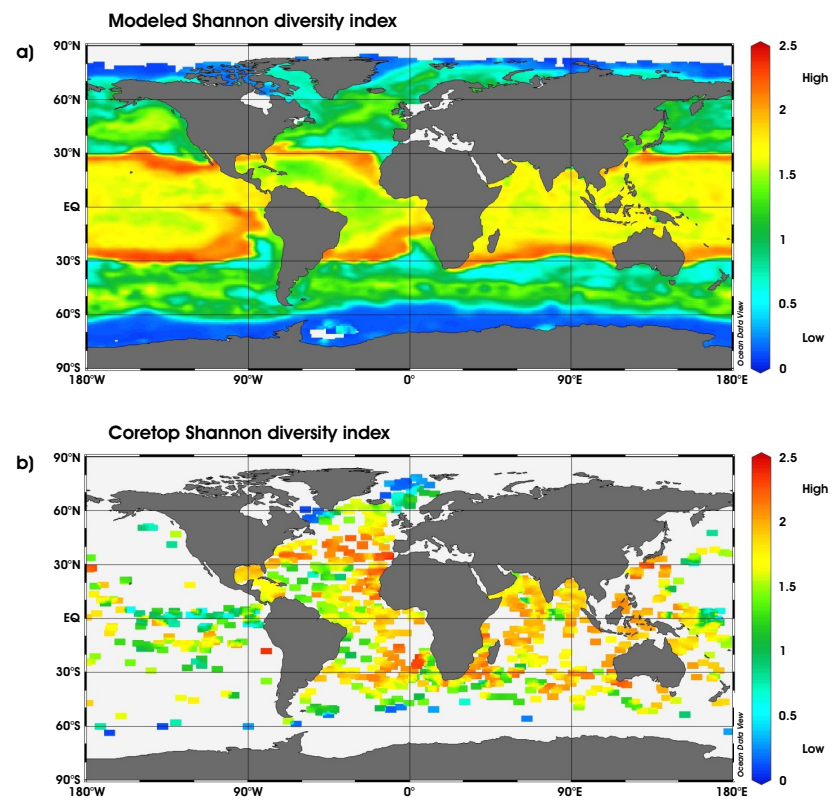

Fig. 4. Species diversity $H$ after Shannon and Weaver (1949) calculated from (a) the model and (b) coretop foraminiferal assemblages (Prell et al., 1999) considering only species included in the model. White and pink G. ruber are combined. Higher values correspond to higher species diversity.

NW-Africa. In turn, calculations for G. siphonifera show maximum abundances in low latitudes of the oligotrophic subtropical gyres especially in the W-Pacific, while Eastern Boundary regions and the eastern equatorial Pacific yield reduced abundances of this species, thus being in good agreement with the seafloor record. In contrast, Figs. 9 and 10 illustrate two species ( $N$. dutertrei and $O$. universa) whose modeled global distribution patterns are not consistent with those of surface sediments. Even though the contribution of $N$. dutertrei to the planktic foraminiferal assemblage is limited to predominantly low latitudes in both model and coretops, modeled peak abundances are found along continental margins, which is not supported by surface sediment data. In turn, maximum coretop abundances in the eastern equatorial Pacific are not reproduced by the model. O. universa shows highest modeled abundances in major upwelling areas, which is in contrast to coretop data. Global distributions of modeled and coretop relative abundances of the other 12 species included in the model can be found in Appendix B (Figs. B1-B12).

\subsection{Seasonal variations of foraminiferal flux - model vs. sediment traps}

To test the predictive skills of the model on a seasonal basis, modeled and measured foraminiferal fluxes were compared for sediment traps not included in the calibration data set. Figures 11 and 12 demonstrate exemplarily results on 
Modeled annual abundance of $N$. pachyderma (sin.) [\%]

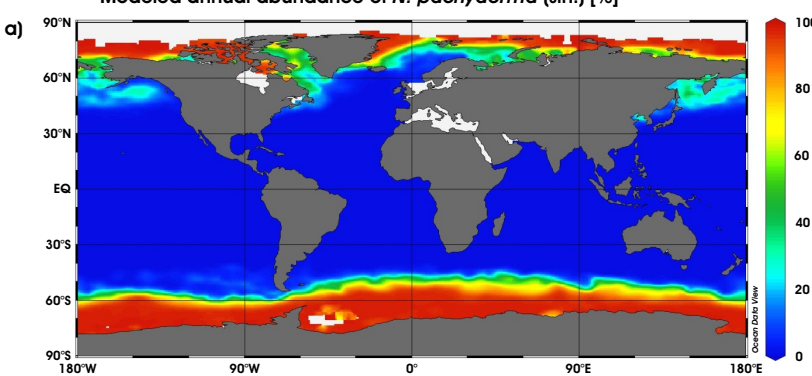

b)

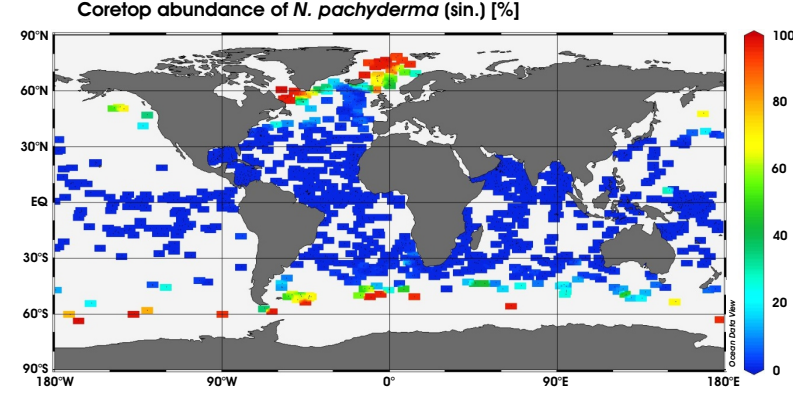

Fig. 5. (a) Modeled annual abundance of N. pachyderma (sin.) [\%], (b) coretop abundance of $N$. pachyderma (sin.) [\%] (Prell et al., 1999). Only species included in the model were considered.
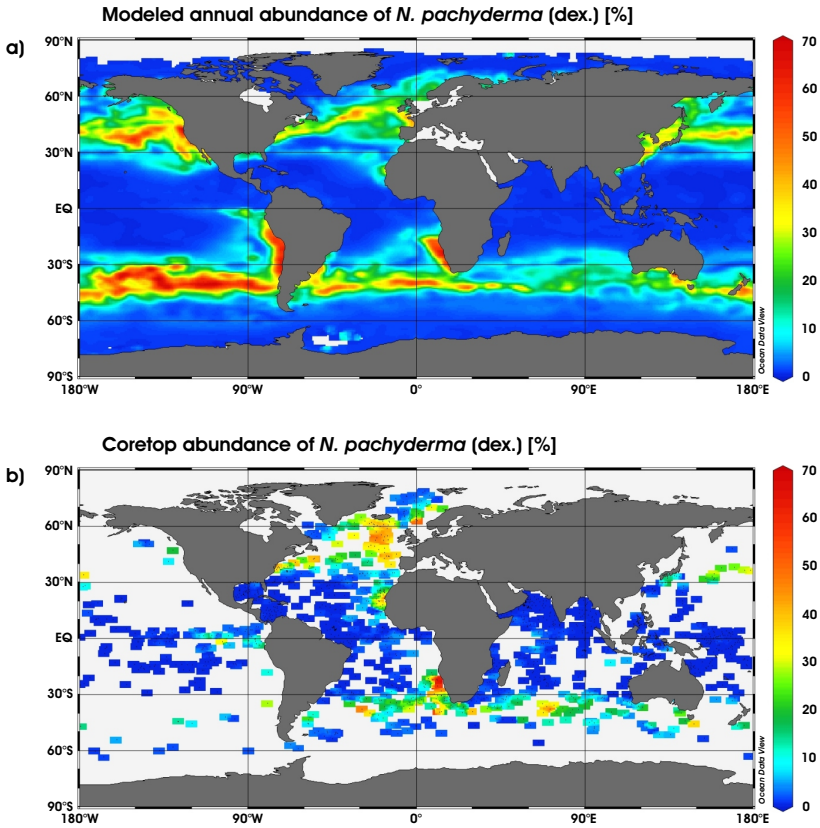

Fig. 6. As in Fig. 5 but for N. pachyderma (dex.).

some species for two sediment traps from the Cariaco Basin and the Somalia upwelling, respectively (Conan and Brummer, 2000; Tedesco and Thunell, 2003; see Table 3). One of the principal results visible in the figures is that absolute foraminiferal fluxes are not properly reproduced by the model. In most cases modeled species fluxes are signifi-
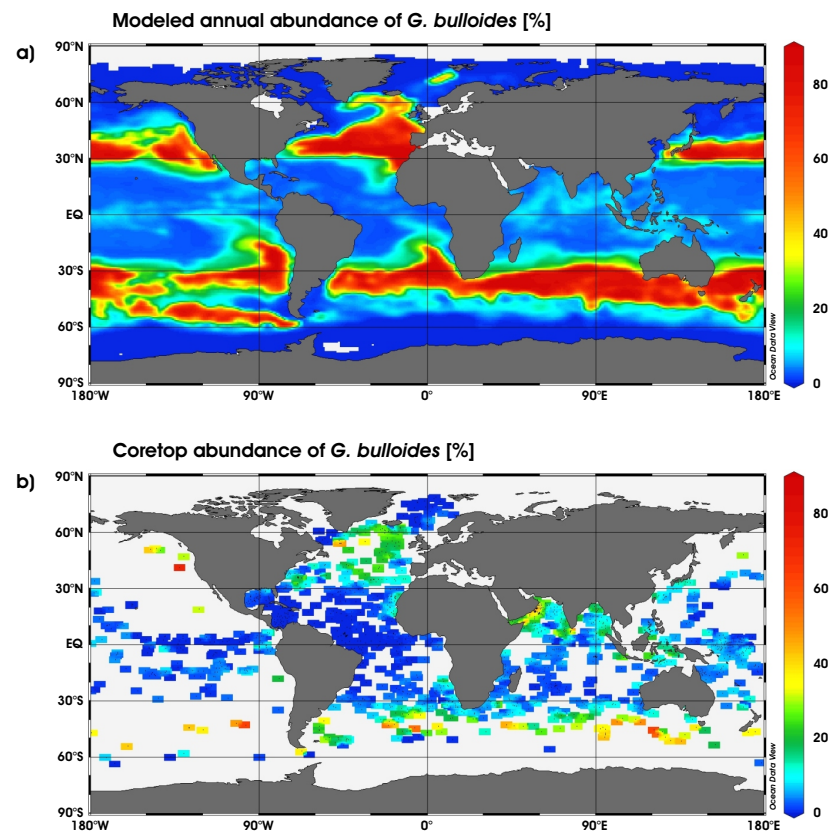

Fig. 7. As in Fig. 5 but for G. bulloides.
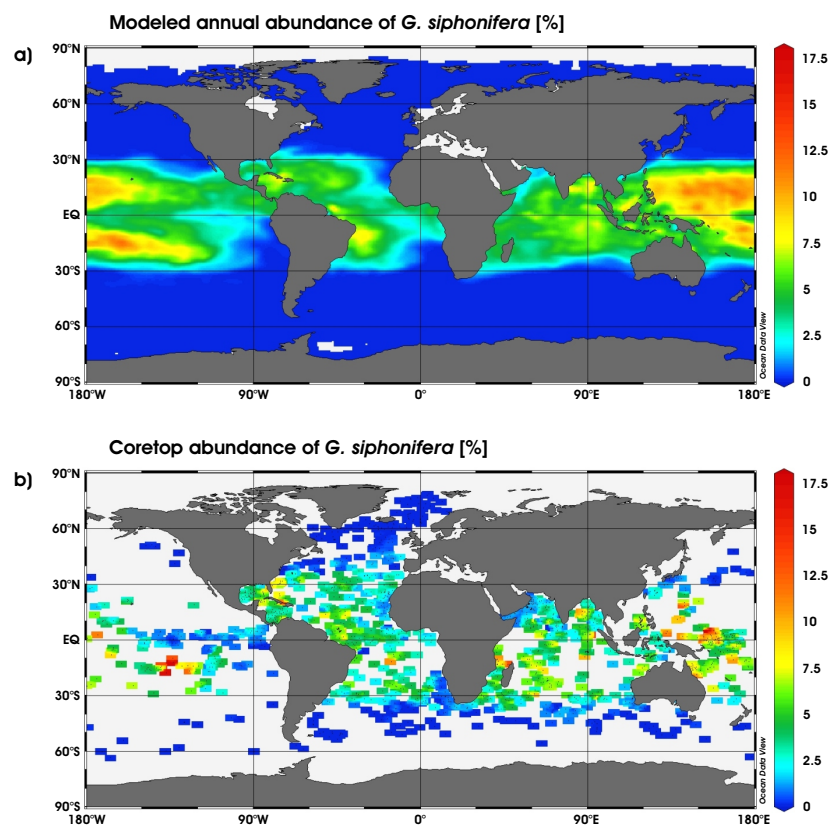

Fig. 8. As in Fig. 5 but for G. siphonifera.

cantly underestimated compared to trap-derived fluxes. Regarding the seasonal pattern of species fluxes we observe some species where predicted fluxes match fairly well with their trap record (e.g. O. universa and G. ruber (white) in Fig. 11, T. quinqueloba and G. glutinata in Fig. 12), while other species at the same stations seem to be out of phase (e.g. G. menardii in Fig. 11 and G. sacculifer in Fig. 12). Interannual variability in the exact timing or magnitude of peak 

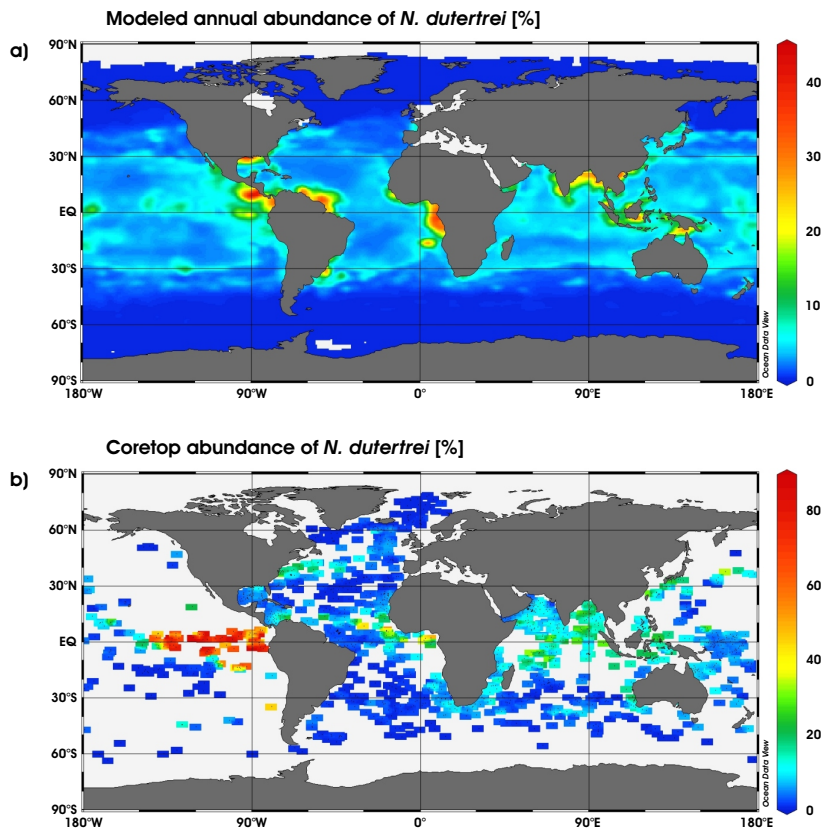

Fig. 9. As in Fig. 5 but for N. dutertrei. Note different scaling of color bars.

fluxes is not reproduced by the model, which can clearly be seen in T. quinqueloba and O. universa fluxes in the Cariaco Basin (Fig. 11). It should be noted, however, that such variability is not properly taken into account in the model due to the forcing, which is partly based on climatological data (MLD) or a single year (PEX; see discussion).

\section{Discussion}

4.1 Model output vs. observations from coretops and sediment traps

The empirical model presented here is, to our knowledge, the first attempt to predict planktic foraminiferal fluxes on a global scale. Many principal distribution patterns of foraminiferal species recognized from the model experiments do match observations in coretops or sediment traps, even though the model still produces problematic outputs in many places.

\subsubsection{Total foraminiferal flux, species richness and diver- sity}

Annually averaged total foraminiferal fluxes calculated by the model are highest in temperate and subpolar waters and low in polar waters and the tropics with minima in the centers of the oligotrophic subtropical gyres reflecting planktic foraminiferal needs for sufficient food supply (Fig. 2). Higher total foraminiferal fluxes were also modeled in lower latitudes associated with Eastern Boundary Currents charac-
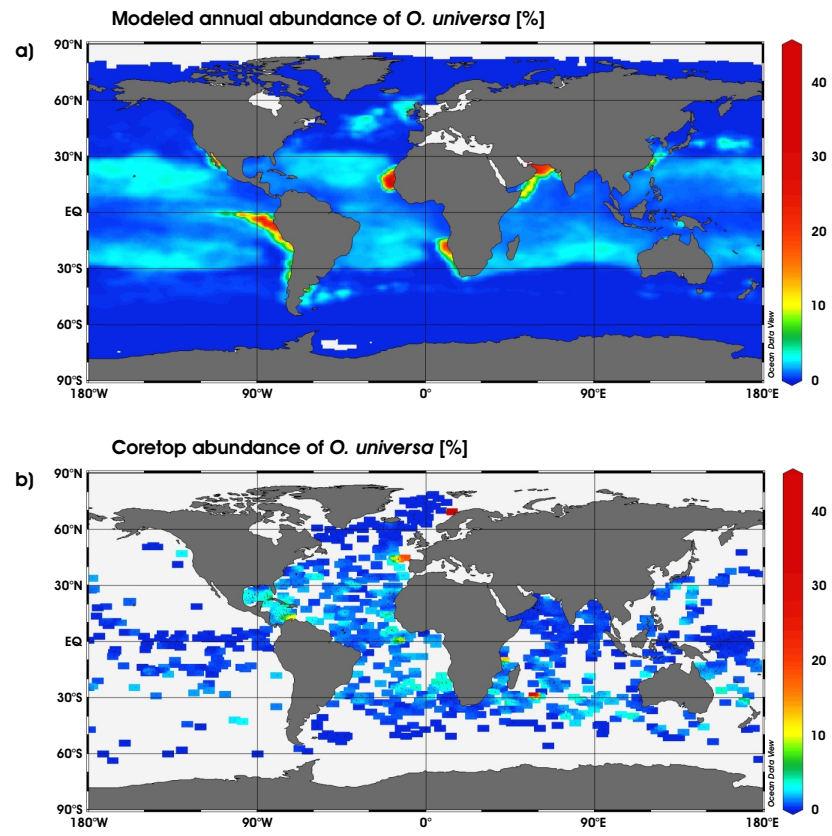

Fig. 10. As in Fig. 5 but for O. universa.

terized by strong coastal upwelling and hence higher producitivty. An increase in fluxes, though rather small, was also calculated for the seasonal upwelling region in the western Arabian Sea and in the equatorial upwelling regions of the Atlantic and Pacific Oceans.

Modeled meridional gradients in species richness and diversity compare favorably with coretop data (Figs. 3 and 4) and are consistent with the general trend of an overall decrease in faunal diversity with increasing latitude (e.g. MacArthur, 1965; Stehli et al., 1969). Analyzing planktic foraminiferal diversity from surface water samples Ottens and Nederbragt (1992) showed that deviations from this global trend are related to specific ocean environments as suggested earlier by Stehli (1965). They demonstrated that water mass boundaries or frontal zones are characterized by high diversity of planktic foraminiferal faunas due to mixing of species from adjacent water masses. On the other hand, they found that variable environments with distinct seasonal or short-term variations in oceanic parameters like in upwelling areas host relatively low diversity faunas as compared to the surrounding environment, which is in good agreement with our model results. Lower absolute values in coretop species richness particularly in the Pacific Ocean might in part be due to selective dissolution of the surface sediments (Berger, 1968; Thunell and Honjo, 1981; Boltovskoy, 1994; Le and Thunell, 1996; Dittert and Henrich, 2000; Conan et al., 2002), as they are exposed to the surrounding seawater much longer than the trap material, which was used in the model calibration. 

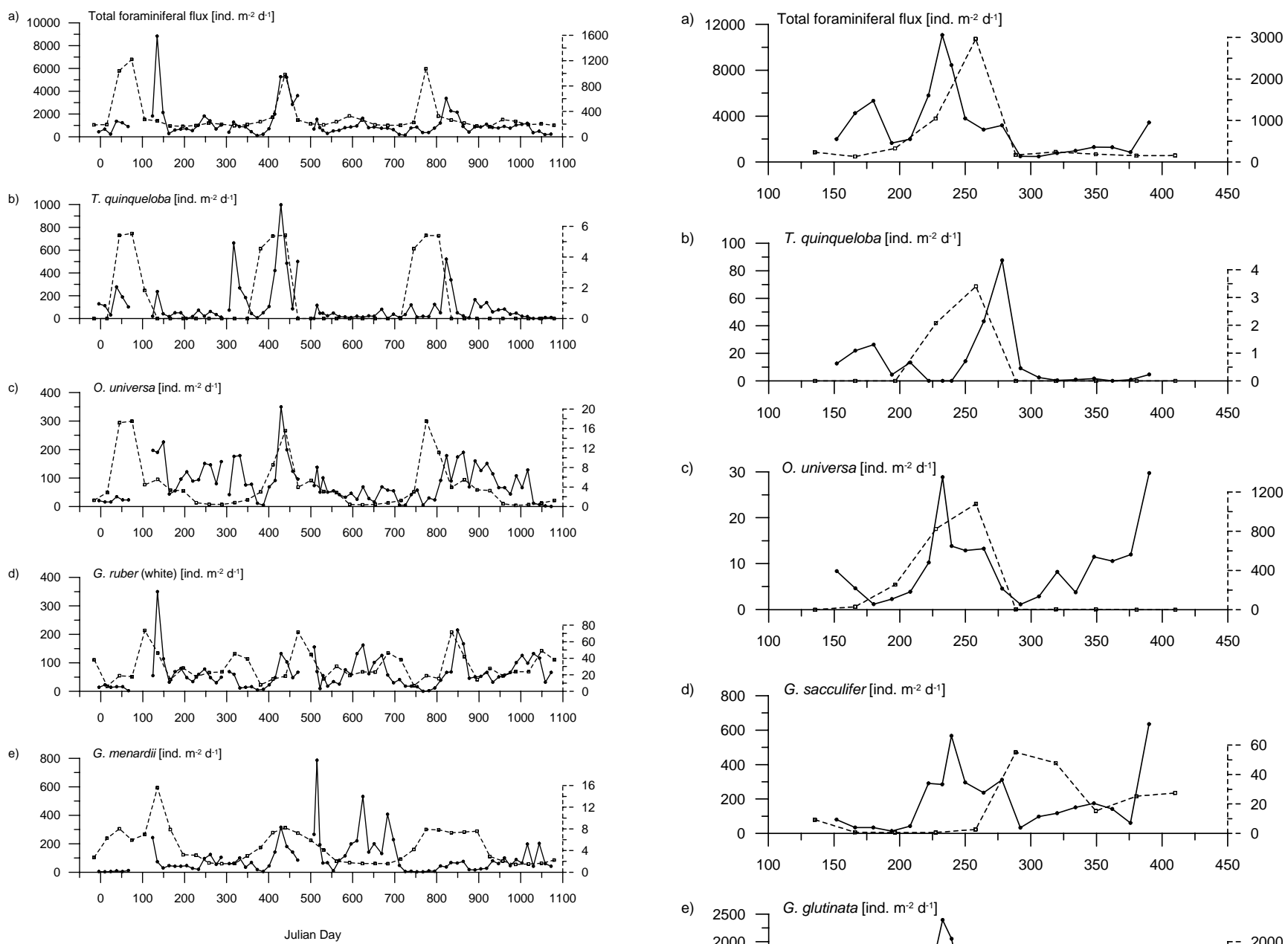

Fig. 11. Comparison of modeled and measured foraminiferal fluxes in [ind. $\mathrm{m}^{-2} \mathrm{~d}^{-1}$ ]. Solid lines/y-axes and filled circles show fluxes measured in the sediment trap in the Cariaco Basin (Tedesco and Thunell, 2003). Dashed lines/y-axes and open squares show fluxes calculated by the model. Note that in this case the model was forced with actual monthly sea-surface temperatures from the time of trap deployment to account at least in part for interannual differences in environmental parameters (see Sect. 2.5). Trap data are plotted 2 weeks prior to their catchment intervals to account for the time-lag applied in the calibration. (a) Total foraminiferal flux considering only species included in the model, (b) T. quinqueloba, (c) O. universa, (d) G. ruber (white), (e) G. menardii, Julian Day $1=1$ January 1997.

\subsubsection{Relative species abundances}

Analyzing annual relative abundances of foraminiferal species has shown that particular patterns in the distribution of some species on the seafloor can also be reproduced by the model. Among these is for example the restriction of significant relative abundances of the cold-water species $N$. pachyderma (sin.) to higher latitudes, where it can account for more than $90 \%$ of the assemblage (Fig. 5). For

$N$. pachyderma (dex.), preferring subpolar to transitional water masses, the modeled relative abundance pattern does not only match the latitudinal distribution but also more complex structures like increased abundances in the major upwelling areas along Eastern Boundary Currents, which are clearly visible in coretops off SW- and NW-Africa (Fig. 6). 

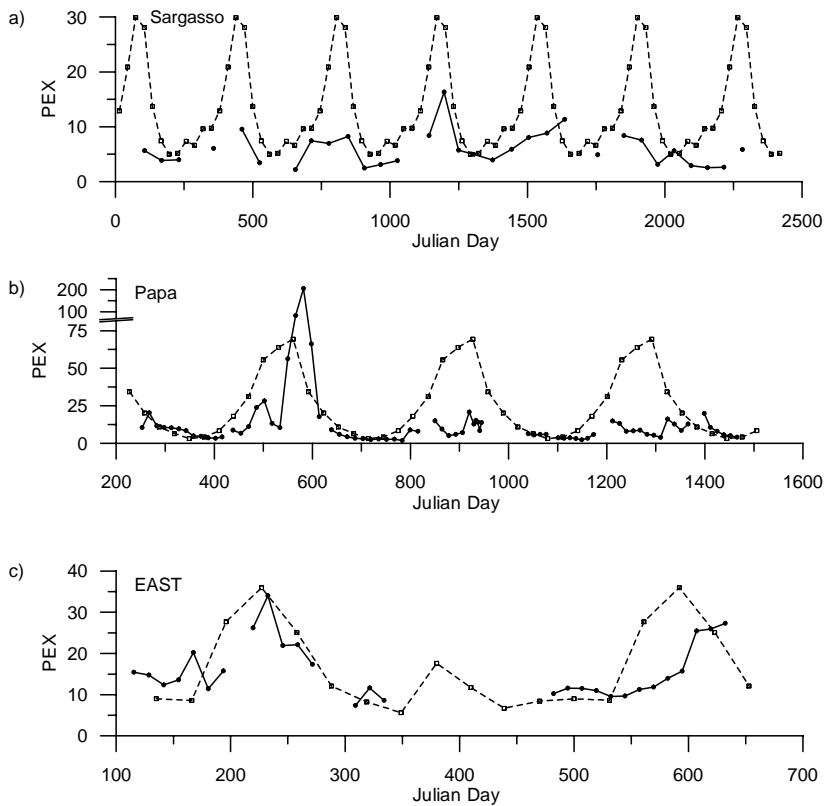

Fig. 13. Comparison of export production values in $1000 \mathrm{~m}$ water depth (PEX) calculated for the calibration and the global data set in $\left[\mathrm{mg} \mathrm{C}_{\mathrm{org}} \mathrm{m}^{-2} \mathrm{~d}^{-1}\right.$ ] for the stations (a) in the Sargasso Sea (Julian Day 1 = 1 January 1978), (b) at Ocean Station Papa (Julian Day 1 = 1 January 1982), and (c) in the eastern Arabian Sea (EAST, Julian Day 1 = 1 January 1986). Solid lines and filled circles show PEX calculated from sediment-trap-derived $\mathrm{C}_{\text {org }}$ fluxes as applied in the model calibration (for references see Table 1). Dashed lines and open squares show PEX calculated from satellite-derived primary productivity as applied for the global model run after Antia et al. (2001). Trap data are plotted 3 weeks prior to their catchment intervals to account for the time-lag applied in the calibration.

Even the higher abundances spreading westward along the eastern equatorial Pacific could be reproduced by the model. As observed from surface sediments, this region and major coastal upwelling areas yield reduced relative abundances of the warm-water species G. siphonifera, which shows high abundances in the oligotrophic subtropical gyres (highest in the W-Pacific). This distribution pattern also compares favorably well with our model results (Fig. 8) as does the latitudinal distribution of G. bulloides abundances (Fig. 7). In contrast, increased relative abundances of G. bulloides in some major upwelling areas (e.g. the western Arabian Sea off Somalia) are not mirrored in the model in spite of a high standardized regression coefficient for PEX* for this species (Table 3). A possible reason might be the bad coverage of very high export productivities in the calibration data set. Only 21 of the 1327 samples yield PEX values above $40 \mathrm{mg} \mathrm{C}_{\text {org }}$ $\mathrm{m}^{-2} \mathrm{~d}^{-1}$ in $1000 \mathrm{~m}$ water depth, which is apparently insufficient to reliably predict foraminiferal fluxes in highly productive upwelling regions. Other examples, in which modeled species distributions significantly deviate from their seafloor record are abundance patterns of $N$. dutertrei and $O$. uni-
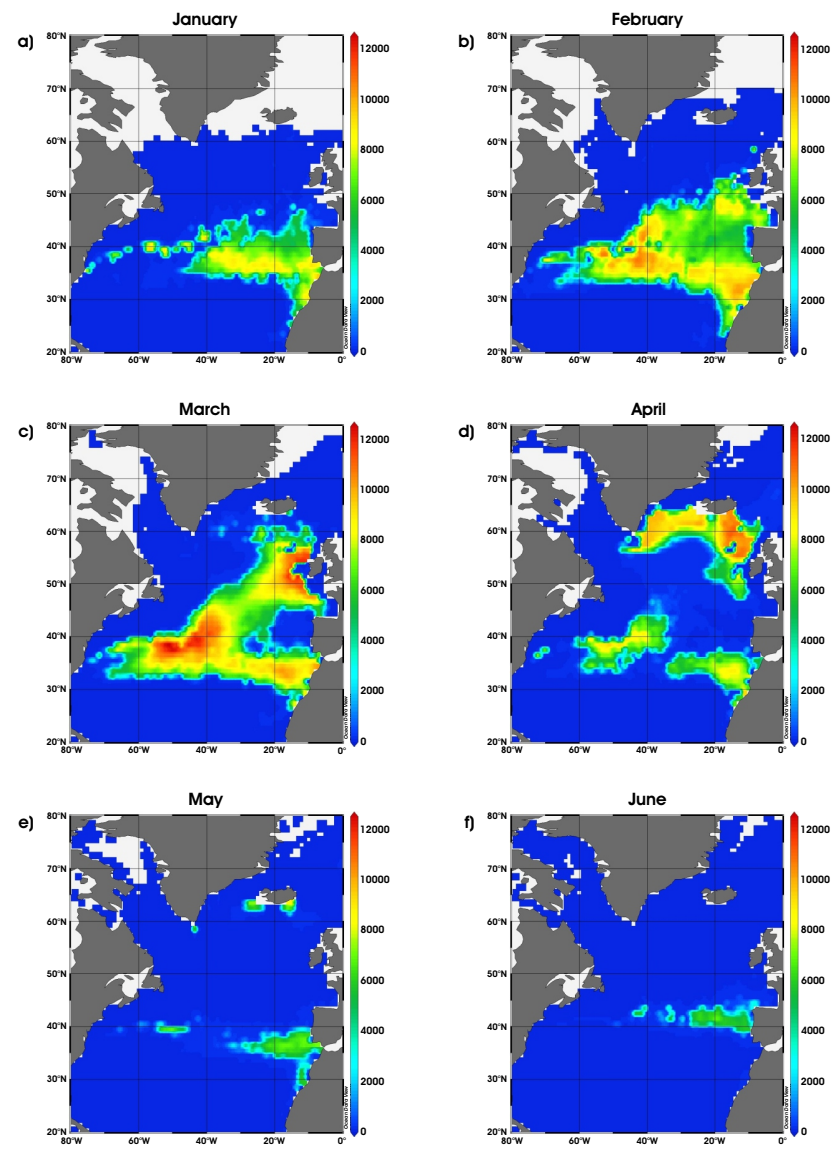

Fig. 14. Modeled monthly fluxes [ind. $\mathrm{m}^{-2} \mathrm{~d}^{-1}$ ] of the species G. bulloides in the N-Atlantic for the months January to June (a-f).

versa (Figs. 9 and 10). Even though both model and coretops show minimal abundances of $N$. dutertrei in higher latitudes, higher abundances from the model do not match observations from coretops and vice versa. The apparent mismatch in the eastern equatorial Pacific might in part be due to a lack of calibration samples from that very special ocean environment.

However, when comparing modeled relative abundances of foraminiferal species with coretop distributions it has to be beared in mind, that the model calculates absolute species fluxes from the environmental input parameters. Hence, the quality of the estimate of relative abundances depends on the performance of all species in the model, so that fluxes of a poorly represented species worsen the results of better reproduced species as well. Surface sediments, on the other hand, can reflect foraminiferal assemblage variations averaged over several decades or several hundred years (depending on sedimentation rates). Such long-term variations are not represented in the model due to the forcing being used. In addition, sedimentary assemblages may be altered by selective dissolution, by displacement through bottom currents or by bioturbation processes (Boltovskoy, 1994). Furthermore, coretops reveal only relative abundances of foraminiferal 
species and do not allow conclusions on absolute species fluxes.

\subsubsection{Absolute species fluxes}

The lack of absolute shell fluxes of foraminiferal species on a global scale makes it difficult to assess the corresponding model data. Bé and co-workers analyzed the geographic distribution of various species in the Atlantic and Indian Oceans using plankton tows, and presented absolute and relative abundances of the planktic foraminiferal standing stocks (Bé and Hamlin, 1967; Bé and Tolderlund, 1971; Bé and Hutson, 1977). But several reasons argue against a comparison of our model results to their distributional maps. First of all, they used plankton nets with a mesh size of $200 \mu \mathrm{m}$ in contrast to the 125 and $150 \mu \mathrm{m}$ sieve size used in the sediment trap studies. Moreover, plankton tow samples represent only snapshots of the foraminiferal assemblages (Boltovskoy et al., 1996) and finally, values of foraminiferal standing stocks cannot be directly translated into downward fluxes of planktic foraminiferal species.

The only alternative to independently test the predictive skills of the model regarding absolute fluxes of planktic foraminifera were several sediment trap studies that were not included in the calibration data set (Table 2, Figs. 11 and 12). One of the principal model results in this context is the significant underestimation of absolute foraminiferal abundances in most cases. This might in part be due to the fact that actual foraminiferal fluxes and relative abundances at certain environmental conditions can be highly variant, as was shown for surface sediment as well as sediment trap databases (Hilbrecht, 1996; Žarić et al., 2005). This variability is not accounted for by the model, which calculates only a single "average" flux for a given set of environmental parameters. These average values are usually comparably small especially because the data set contains a high number of "void observations" (see methods Sect. 2.1). Despite the fact that absolute foraminiferal fluxes are not adequately predicted by the model in most cases, the seasonal signal of species fluxes compares fairly well to sediment trap records for some species. For example, high fluxes of T. quinqueloba, O. universa and G. ruber (white) in the Cariaco Basin (Fig. 11) and of G. glutinata in the Arabian Sea (Fig. 12) occur at similar times in the model as they were in fact recorded by the sediment traps. At the same time other species like G. menardii in the Cariaco Basin and G. sacculifer in the Somalia upwelling are sometimes out of phase in the model. Further species have barely any seasonality in fluxes even though the sediment trap record shows high peak fluxes at certain times (e.g. G. bulloides in the Cariaco Basin, not shown). Considering all species on a global scale, we could not detect any global systematic error in the predicted fluxes neither regarding their magnitude nor their seasonality for any species.

\subsection{Pitfalls and potential of the model}

Some of the discrepancies between modeled and observed foraminiferal flux patterns may be due to an insufficient calibration of the model. For an optimal calibration it would be necessary to have actual hydrographical as well as productivity data on timescales at which the sediment traps operate (in the order of weeks). Such data were only available for SST (Reynolds and Smith, 1994). The MLD had to be calculated from climatological temperature and salinity data (Conkright et al., 2002). Thus, information on interannual differences of the mixed layer is lost, and potential subsequent variations of foraminiferal fluxes are inadequately reflected in the hydrographic parameters of the calibration data set. The same is true when comparing the modeled seasonal signal of foraminiferal assemblages with measured foraminiferal fluxes of sediment traps not included in the calibration. The model was forced with long-term mean values of MLD, and PEX values of an exemplary year, which may deviate significantly from the actual situation that the foraminifera were living in prior to settling into the trap. Again, information on the variability of the environmental input parameters cannot be taken into account, and the model is not able to reproduce interannual changes in foraminiferal fluxes (Fig. 11), which can be significant (e.g. Sautter and Thunell, 1989; Tedesco and Thunell, 2003; Marchant et al., 2004).

Export production estimates introduce the largest uncertainty into the model, because export ratios should vary over the course of the year due to seasonally changing productivity patterns, but so far there are no algorithms on organic carbon transfer efficiencies based on shorter than annual timescales. Moreover, we had to use a different approach for the calculation of PEX in the global data set than for the PEX calculation applied in the calibration (see methods Sects. 2.1 and 2.3). Whereas we could normalize trapmeasured organic carbon fluxes to $1000 \mathrm{~m}$ in the calibration (Martin et al., 1987; Francois et al., 2002), we had to calculate export production from satellite-derived primary production data of an exemplary year after Antia et al. (2001) in order to obtain monthly PEX values for our global data set. The comparability of both approaches remains an open question. Comparing PEX values from both our calibration as well as our global data set at the positions of the sediment traps shows that both PEX values are comparable at some positions/times but that in many cases satellite-derived values can be significantly higher than trap-derived values for other positions/times (Fig. 13). This means that the model often calculates foraminiferal fluxes at higher export productions than those recorded in the calibration data set for the same position.

As the quantification of downward organic carbon fluxes as well as their relationship to primary production in surface waters are still subject to intensive discussions (e.g. Buesseler, 1998; Laws et al., 2000; Antia et al., 2001; Armstrong et al., 2002; Francois et al., 2002; Lutz et al., 2002; 
Schlitzer, 2002b), the export production in $1000 \mathrm{~m}$ water depth is probably not well suited as an environmental input parameter for a planktic foraminiferal flux model. We decided to still use export production, because it was the only productivity-related parameter being available in the temporal resolution of sediment trap samples. However, it would be generally useful to replace the PEX variable in the model by a primary-production dependent variable, which would be a more realistic representation of food availability for planktic foraminifera. Low coefficients of determination $\left(r^{2}\right.$ between 0.29 and 0.75 ) calculated in the statistical model calibration already suggest that the three environmental parameters SST, MLD and PEX used here are not sufficient to describe the fluxes of all planktic foraminiferal species considered and that additional parameters should be included in the model. Numerous studies revealed that productivity often being linked to the nutrient content is a significant factor influencing planktic foraminiferal fluxes and assemblage compositions (e.g. Bé and Hutson, 1977; Ortiz et al., 1995; Watkins et al., 1996; Eguchi et al., 1999; Schiebel et al., 2001; Morey et al., 2005). In this context it would also be reasonable not to correlate species fluxes exclusively to conditions at the sea surface but to consider different water depths as well to include the occurrence of deep chlorophyll maxima that some foraminifera like $N$. pachyderma or $N$. dutertrei have often been associated with at least for part of their life cycles (e.g. Fairbanks and Wiebe, 1980; Fairbanks et al., 1982; Reynolds and Thunell, 1986; Kohfeld et al., 1996).

Other environmental conditions not included in our model so far, that have been supposed to have an impact on planktic foraminiferal fluxes and assemblage compositions are light intensity, circulation patterns or salinity (e.g. Bijma et al., 1990b; Ortiz et al., 1995; Watkins et al., 1996; Guptha et al., 1997). Based on studies of laboratory cultures (Bijma et al., 1990b) and coretop sediments (Morey et al., 2005) that suggest that salinity does not have a significant effect on foraminiferal species distributions in modern oceans, we decided to omit salinity in our model to avoid enhanced multicolinearity, since salinity is often highly correlated with SST.

Several factors potentially contributing to noise or error in the calibration data set have been discussed by Žarić et al. (2005) and shall only briefly be mentioned here. Among these are a patchy distribution of foraminifera in the ocean (e.g. Bé and Hutson, 1977), foraminiferal life cycles (e.g. Bé, 1977; Bijma et al., 1990a, 1994), differences in sinking velocities of foraminiferal shells (e.g. Takahashi and Bé, 1984; Bijma et al., 1994), a lateral component in particle fluxes (e.g. Freudenthal et al., 2001; Wilke et al., 2005 ${ }^{1}$ ), the presence of distinct genotypes within certain morphospecies having distinct ecological preferences (e.g. summarized in Kucera and Darling, 2002), the trapping efficiency

\footnotetext{
${ }^{1}$ Wilke, I., Meggers, H., and Bickert, T.: Seasonal distribution and stable oxygen isotope composition of planktic foraminifera off NW-Africa $\left(29^{\circ} \mathrm{N}\right)$, Deep-Sea Res. I, submitted, 2005.
}

of sediment traps (Scholten et al., 2001; Yu et al., 2001) and the taxonomic consistency of the planktic foraminiferal studies used here. Furthermore, in the sediment-trap investigations included here two different sieve sizes were used for foraminiferal analyses (125 and $150 \mu \mathrm{m}$, respectively). As was shown by Carstens et al. (1997), species flux and relative abundance can differ significantly when the minimum size of the counted foraminifera is changed. Within the scope of this investigation, however, we have to use every available data set, and most of the data were available in the given size fraction only.

Nevertheless, even though the model presented here produces problematic outputs in some places, many general distribution patterns of planktic foraminifera can be recognized. The potential of such a foraminiferal flux model to be used for paleoreconstructions by identifying seasonal flux signals for certain species shall be illustrated on the following example. Figure 14 shows modeled monthly fluxes (January to June) for the species G. bulloides in the N-Atlantic. Peak fluxes are calculated for spring (March) with high fluxes occurring first in more southerly parts around $40^{\circ} \mathrm{N}$ in January/February and then migrating northward through March and April. Thus our model might confirm results from isotopic studies on NE-Atlantic surface sediments by Ganssen and Kroon (2000), who classified G. bulloides as a species typical of the spring bloom rather than reflecting summer temperatures.

The model presented here is static in the sense that it runs independently for every species, grid-point and month. It carries out every calculation based exclusively on "actual" values of environmental parameters, not taking into account previous hydrographic situations or foraminiferal standing stocks. Adding a dynamic component to the model might thus improve it significantly. In that case the new state of the model would be calculated memorizing the current state and adding a certain rate of change according to changes of the environmental parameters. An important step towards this direction would be coupling our model to current ecosystem models as described by Moore et al. (2001, 2004), which could provide necessary state variables of the pelagic ecosystem.

\section{Summary and conclusions}

(1) The empirical model described here is, to our knowledge, the first attempt to globally predict planktic foraminiferal fluxes at species level depending on the environmental parameters sea-surface temperature, mixed-layer depth and export production. It was calibrated using a combination of sediment trap as well as hydrographic data and forced with a global data set of SST, MLD and PEX to calculate monthly foraminiferal fluxes.

(2) Annually averaged total foraminiferal fluxes calculated by the model peak in temperate and subpolar waters and 
are lowest in polar waters and the tropics reflecting planktic foraminiferal needs for sufficient food supply. Many principal distribution patterns of foraminiferal species predicted by the model compare favorably with observations from coretops, among others meridional gradients in species richness and diversity, increased relative abundances of $N$. pachyderma (dex.) in major upwelling areas, and peak abundances of G. siphonifera in oligotrophic subtropical gyres. In contrast, relative abundance patterns of some other species are not properly reproduced by the model.

(3) Comparisons between modeled and observed planktic foraminiferal fluxes revealed that absolute downward fluxes are significantly underestimated in most cases. Nevertheless, modeled seasonal flux variations match fairly well with the sediment trap record for some species. Interannual flux variations could not be properly reproduced, possibly because of a lack of actual environmental data for calibration and forcing purposes. Hence, our study stresses the importance of acquiring actual data on environmental parameters while conducting sediment trap experiments to ensure that the hydrographic situation is properly monitored.

(4) The limited predictive skills of the model suggest that additional environmental information should be considered such as a more realistic representation of food availability at different habitat depths of planktic foraminiferal species. This could be achieved by adding a dynamic component to the model and linking it to an ecosystem model.

\section{Appendix A}

Table A1. Sea-surface temperature ranges for the species included in the model. Ranges were derived as outlined in Žarić et al. (2005). Outside of these ranges, modeled foraminiferal species fluxes are set to zero.

\begin{tabular}{lcc}
\hline Species & \multicolumn{2}{c}{ SST range } \\
& from & to \\
\hline G. bulloides & 1.9 & 31.0 \\
G. calida & 9.3 & 31.0 \\
G. siphonifera & 11.9 & 31.0 \\
G. glutinata & 1.9 & 31.0 \\
G. ruber (pink) & 16.4 & 29.6 \\
G. ruber (white) & 9.8 & 31.0 \\
G. sacculifer & 9.7 & 31.0 \\
G. inflata & 1.9 & 29.6 \\
G. menardii & 13.3 & 30.5 \\
G. scitula & 2.0 & 29.8 \\
G. truncatulinoides & 3.5 & 29.8 \\
G. rubescens & 16.3 & 29.8 \\
N. dutertrei & 2.6 & 31.0 \\
N. pachyderma (dex.) & -1.8 & 29.8 \\
N. pachyderma (sin.) & -1.8 & 23.7 \\
O. universa & 6.1 & 29.7 \\
P. obliquiloculata & 16.4 & 30.0 \\
T. quinqueloba & -1.8 & 25.9 \\
\hline
\end{tabular}




\section{Appendix B}

Modeled annual abundance of G. calida [\%]

a)
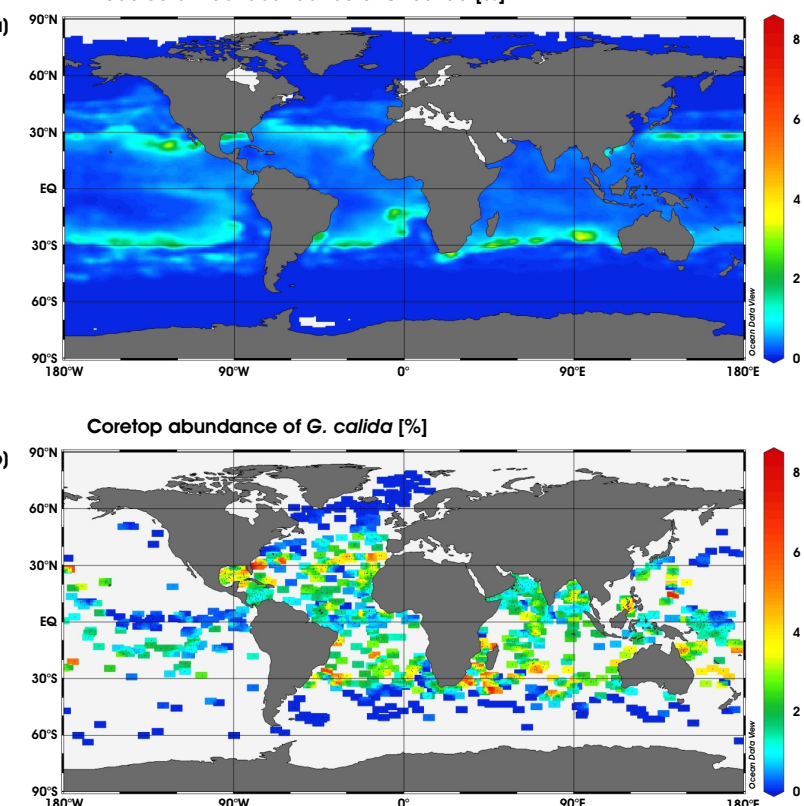

Fig. B1. (a) Modeled annual abundance of G. calida [\%], (b) coretop abundance of G. calida [\%] (Prell et al., 1999). Only species included in the model were considered.
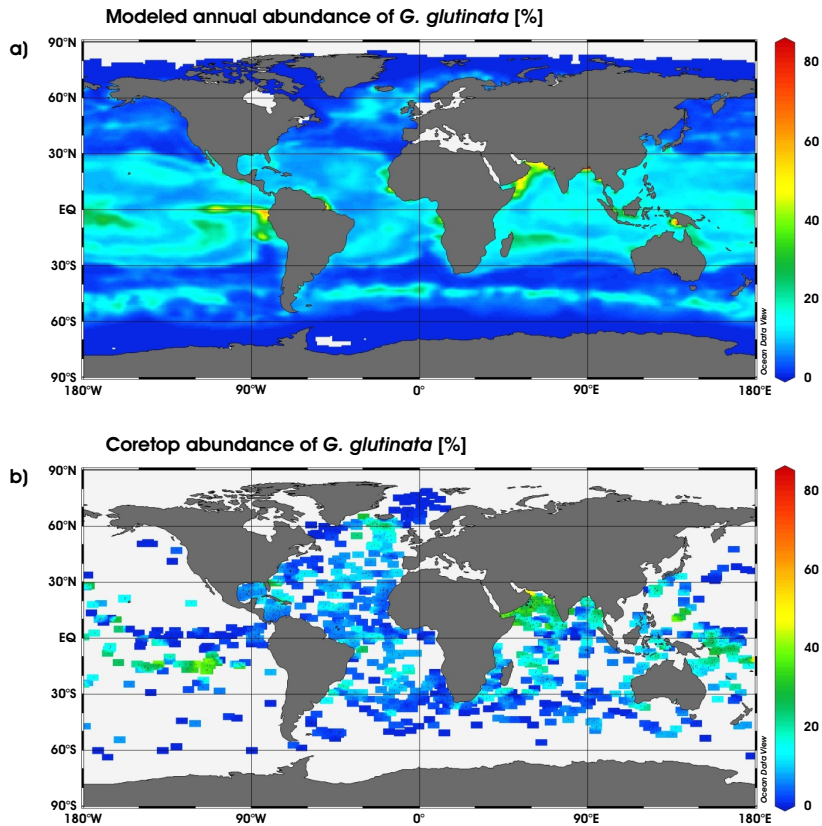

Fig. B2. As in Fig. B1 but for G. glutinata.
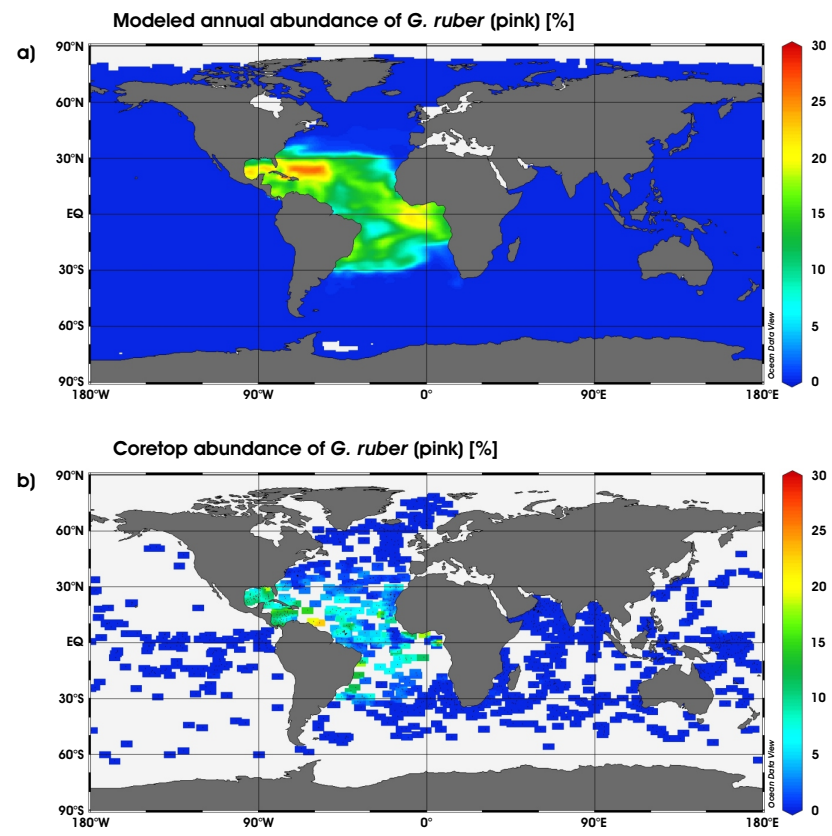

Fig. B3. As in Fig. B1 but for G. ruber (pink).
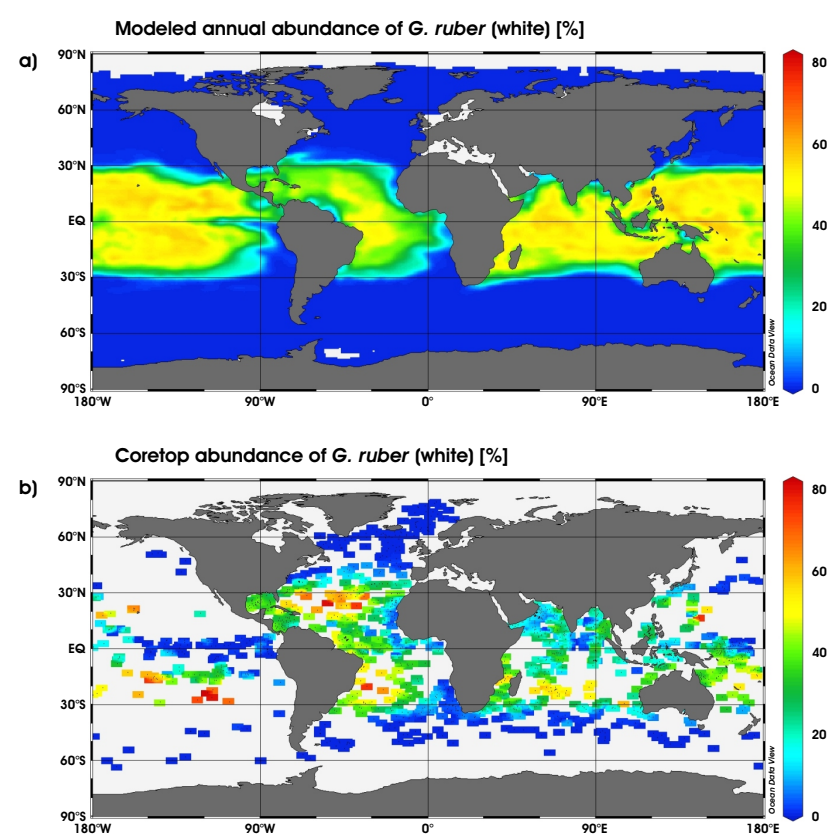

Fig. B4. As in Fig. B1 but for G. ruber (white). 

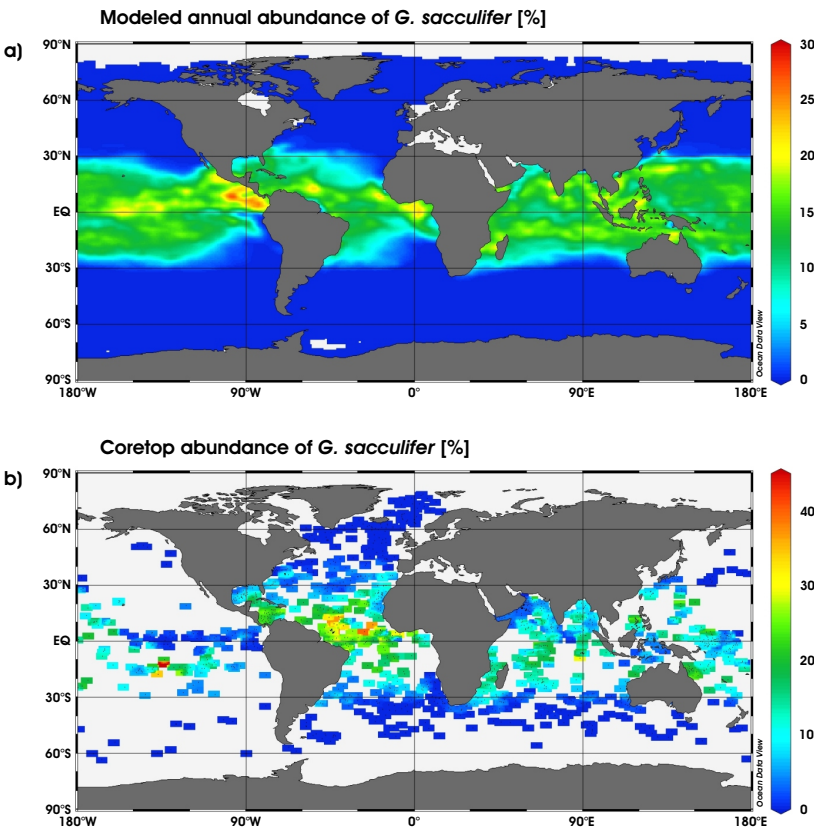

Fig. B5. As in Fig. B1 but for G. sacculifer. Note different scaling of color bars.
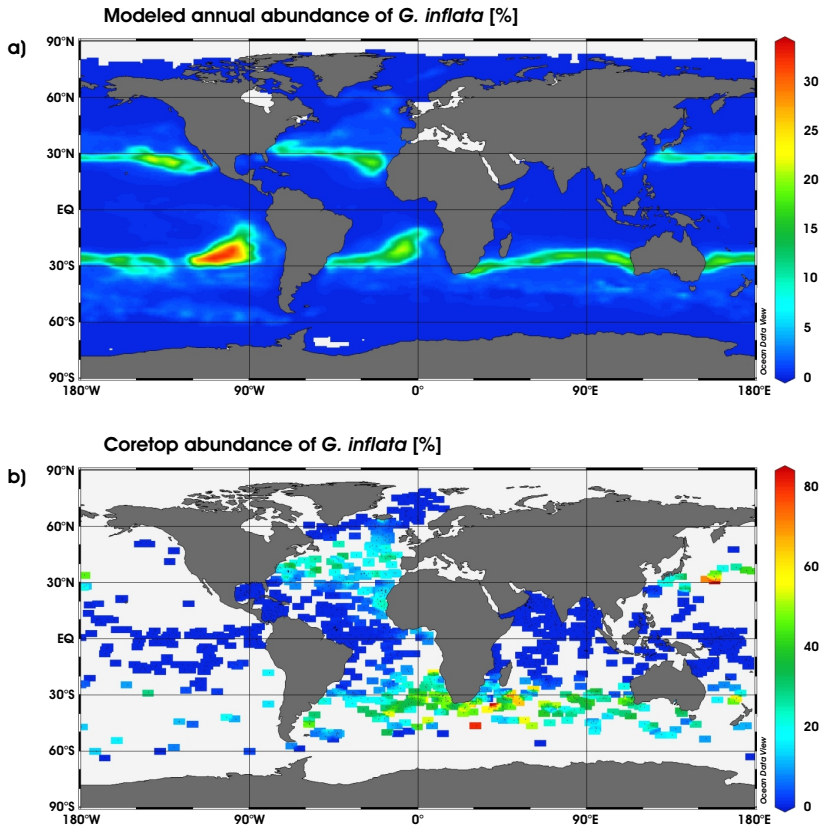

Fig. B6. As in Fig. B1 but for G. inflata. Note different scaling of color bars.
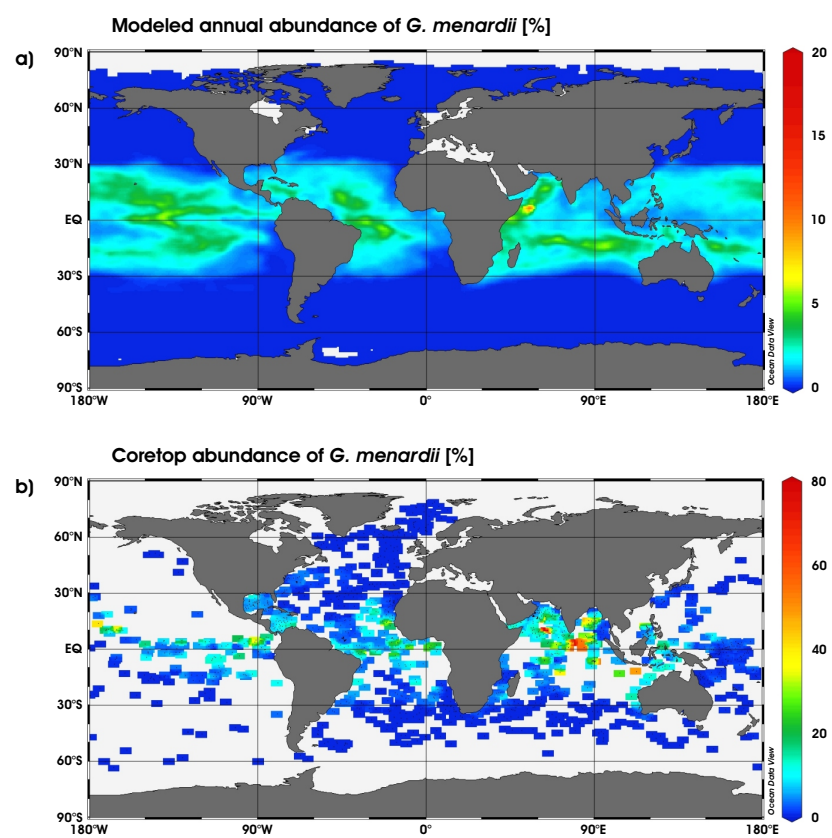

Fig. B7. As in Fig. B1 but for G. menardii. Note different scaling of color bars.
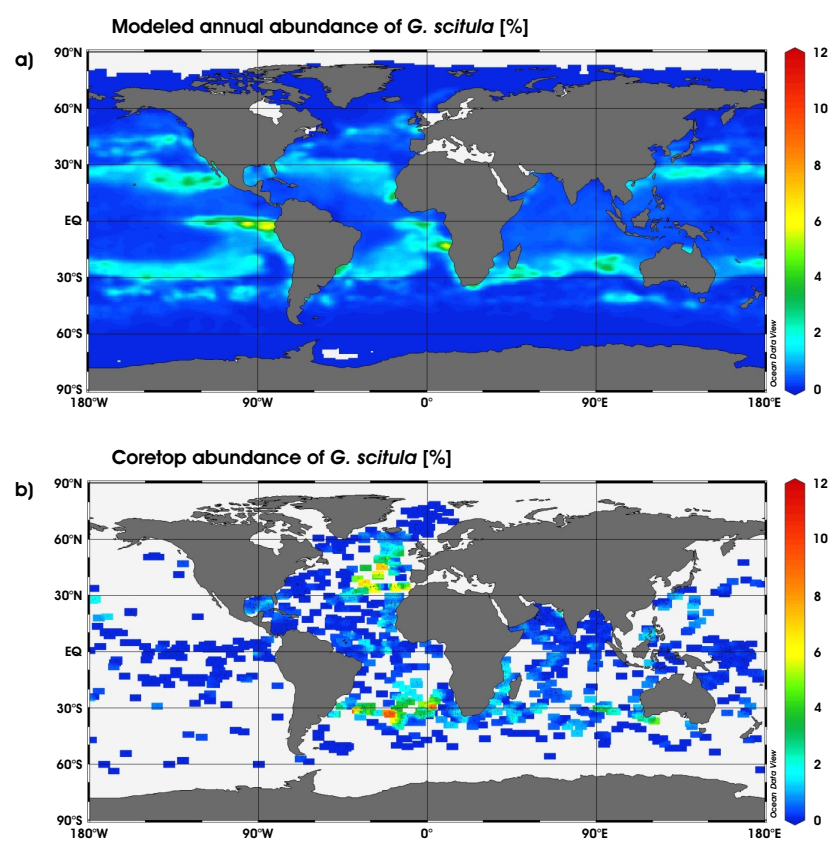

Fig. B8. As in Fig. B1 but for G. scitula. 

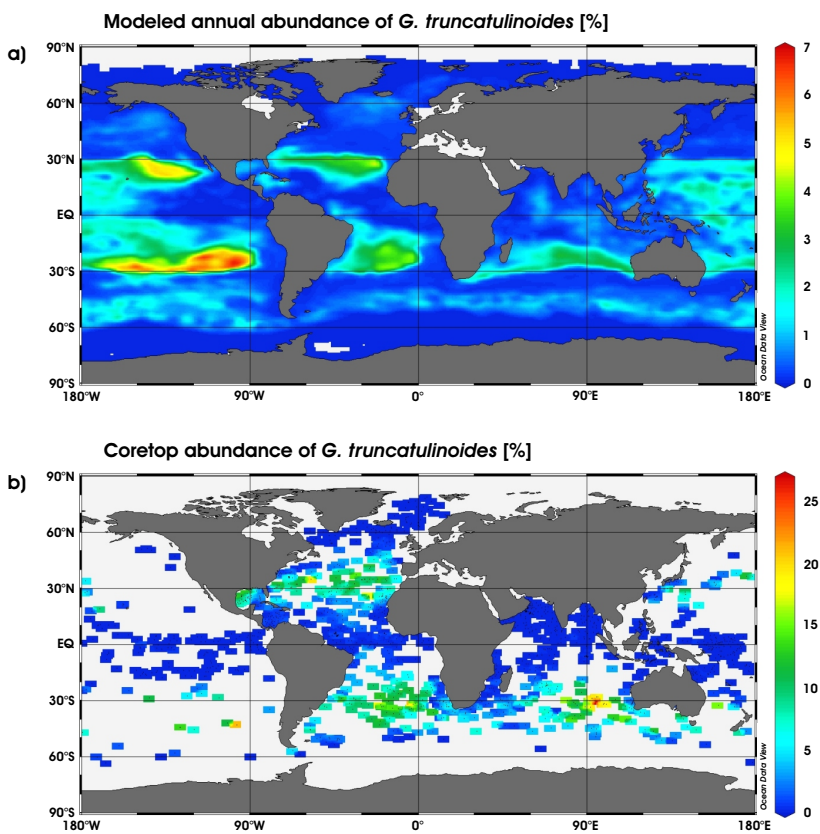

Fig. B9. As in Fig. B1 but for G. truncatulinoides. Note different scaling of color bars.
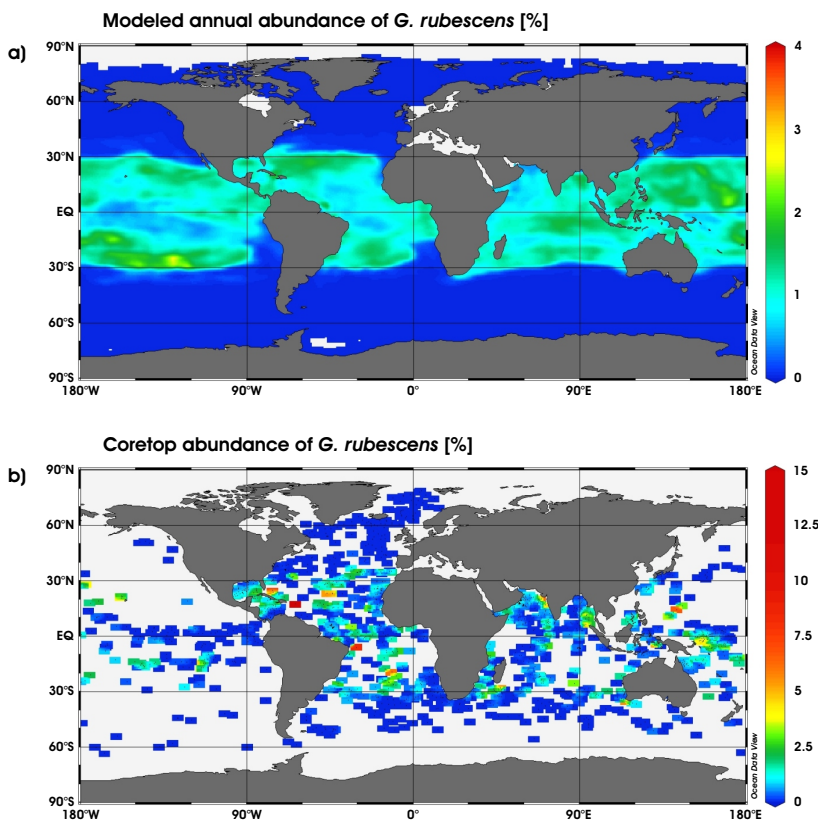

Fig. B10. As in Fig. B1 but for G. rubescens. Note different scaling of color bars.
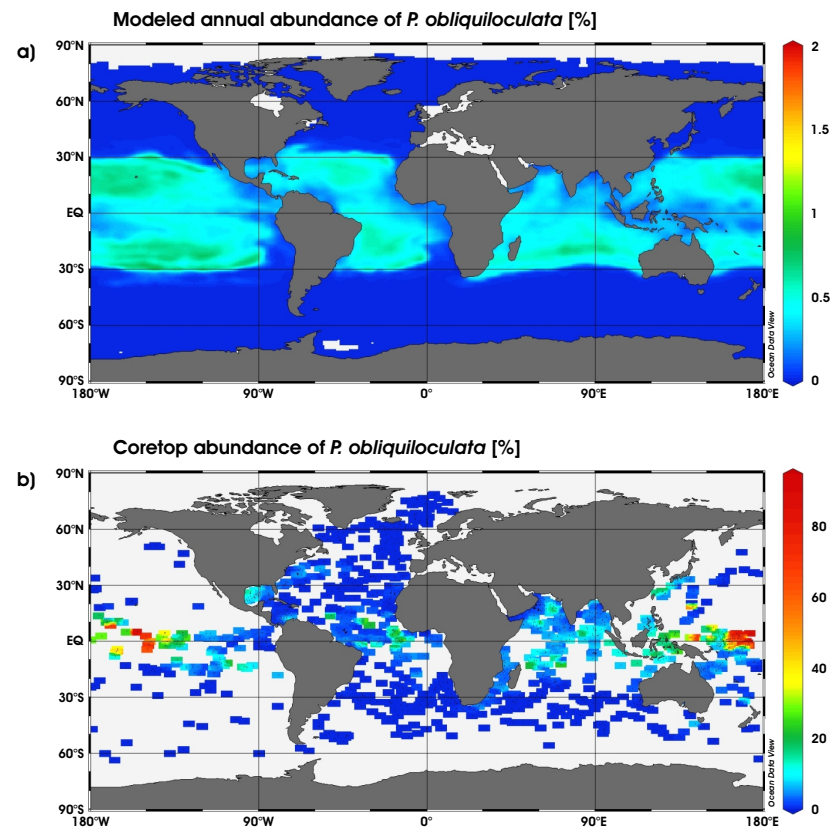

Fig. B11. As in Fig. B1 but for P. obliquiloculata. Note different scaling of color bars.
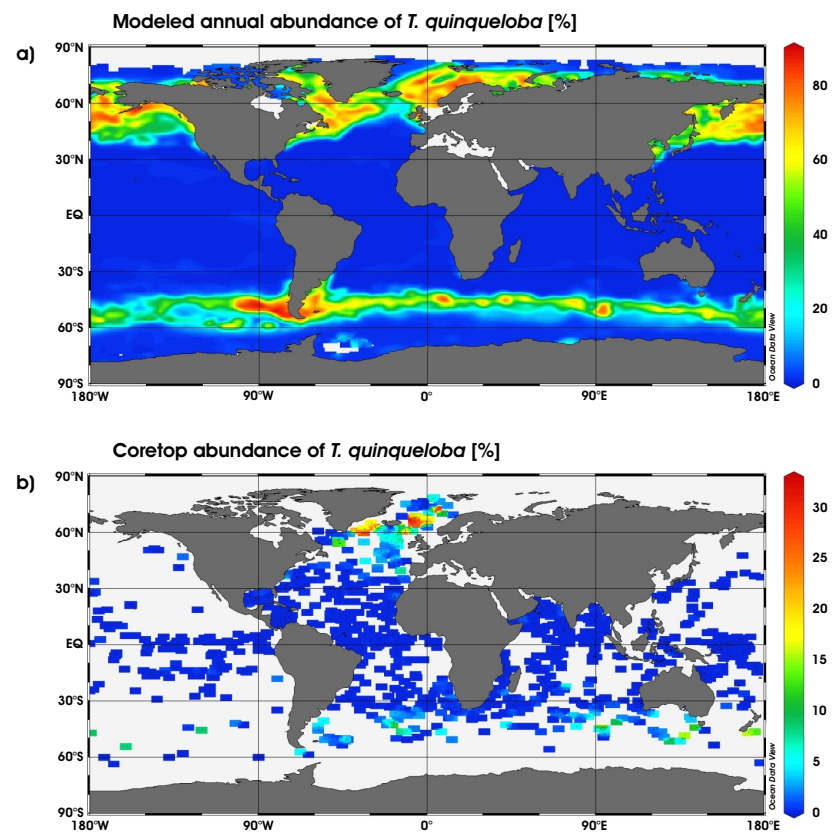

Fig. B12. As in Fig. B1 but for T. quinqueloba. Note different scaling of color bars. 
Acknowledgements. We wish to thank R. Davenport for his great assistance with the satellite primary productivity data. We are also grateful to R. Peinert and A. Antia as well as F. Peeters for generously providing digital-format flux data from the northern $\mathrm{N}$-Atlantic trap sites and the MST8-B station, respectively. Thanks are extended to numerous unnamed colleagues, who previously contributed to the extensive data set used here. We greatly appreciate constructive comments and helpful suggestions by R. Schiebel, G. Ganssen and E. Cortijo, which helped to thoroughly improve the manuscript. This work was supported by the Deutsche Forschungsgemeinschaft as part of the DFG Research Center Ocean Margins of the University of Bremen, No. RCOM0323.

Edited by: J. Bijma

\section{References}

Abrantes, F., Meggers, H., Nave, S., Bollman, J., Palma, S., Sprengel, C., Henderiks, J., Spies, A., Salgueiro, E., Moita, T., and Neuer, S.: Fluxes of micro-organisms along a productivity gradient in the Canary Islands region $\left(29^{\circ} \mathrm{N}\right)$ : implications for paleoreconstructions, Deep-Sea Res. II, 49, 3599-3629, 2002.

Antia, A. N., Koeve, W., Fischer, G., Blanz, T., Schulz-Bull, D., Scholten, J., Neuer, S., Kremling, K., Kuss, J., Peinert, R., Hebbeln, D., Bathmann, U., Conte, M., Fehner, U., and Zeitzschel, B.: Basin-wide particulate carbon flux in the Atlantic Ocean: Regional export patterns and potential for atmospheric $\mathrm{CO}_{2}$ sequestration, Global Biogeochem. Cycles, 15, 845-862, 2001.

Armstrong, R. A., Lee, C., Hedges, J. I., Honjo, S., and Wakeham, S. G.: A new, mechanistic model for organic carbon fluxes in the ocean based on the quantitative association of POC with ballast minerals, Deep-Sea Res. II, 49, 219-236, 2002.

Bé, A. W. H.: An Ecological, Zoogeographic and Taxonomic Review of Recent Planktonic Foraminifera, in: Oceanic Micropalaeontology, edited by: Ramsay, A. T. S., pp. 1-100, Academic Press Inc., London, 1977.

Bé, A. W. H. and Hamlin, W. H.: Ecology of Recent planktonic foraminifera, Micropal., 13, 87-106, 1967.

Bé, A. W. H. and Tolderlund, D. S.: Distribution and ecology of living planktonic foraminifera in surface waters of the Atlantic and Indian Oceans, in: The Micropalaeontology of Oceans, edited by: Funnell, B. M. and Riedel, W. R., pp. 105-149, Cambridge University Press, 1971.

Bé, A. W. H. and Hutson, W. H.: Ecology of planktonic foraminifera and biogeographic patterns of life and fossil assemblages in the Indian Ocean, Micropal., 23, 369-414, 1977.

Berger, W. H.: Planktonic Foraminifera: selective solution and paleoclimatic interpretation, Deep-Sea Res., 15, 31-43, 1968.

Bijma, J., Erez, J., and Hemleben, C.: Lunar and Semi-Lunar Reproductive Cycles in some Spinose Planktonic Foraminifers, J. Foram. Res., 20, 117-127, 1990a.

Bijma, J., Faber, W. W. J., and Hemleben, C.: Temperature and salinity limits for growth and survival of some planktonic foraminifers in laboratory cultures, J. Foram. Res., 20, 95-116, 1990b.

Bijma, J., Hemleben, C., and Wellnitz, K.: Lunar-influenced carbonate flux of the planktic foraminifer Globigerinoides sac- culifer (Brady) from the central Red Sea, Deep-Sea Res. I, 41, 511-530, 1994.

Boltovskoy, D.: The sedimentary record of pelagic biogeography, Prog. Oceanogr., 34, 135-160, 1994.

Boltovskoy, E., Boltovskoy, D., Correa, N., and Brandini, F.: Planktic foraminifera from the southwestern Atlantic $\left(30^{\circ}-60^{\circ} \mathrm{S}\right)$ : species-specific patterns in the upper $50 \mathrm{~m}$, Mar. Micropal., 28, 53-72, 1996.

Breiman, L. and Friedman, J. H.: Estimating Optimal Transformations for Multiple Regression and Correlation, J. Am. Stat. Assoc., 80, 580-598, 1985.

Buesseler, K. O.: The decoupling of production and particulate export in the surface ocean, Global Biogeochem. Cycles, 12, 297310, 1998.

Carstens, J., Hebbeln, D., and Wefer, G.: Distribution of planktic foraminifera at the ice margin in the Arctic (Fram Strait), Mar. Micropal., 29, 257-269, 1997.

Conan, S. M.-H. and Brummer, G.-J. A.: Fluxes of planktic foraminifera in response to monsoonal upwelling on the Somalia Basin margin, Deep-Sea Res. II, 47, 2207-2227, 2000.

Conan, S. M.-H., Ivanova, E. M., and Brummer, G.-J. A.: Quantifying carbonate dissolution and calibration of foraminiferal dissolution indices in the Somali Basin, Mar. Geol., 182, 325-349, 2002.

Conkright, M. E., Locarnini, R. A., Garcia, H. E., O’Brien, T. D., Boyer, T. P., Stephens, C., and Antonov, J. I.: World Ocean Atlas 2001: Objective Analyses, Data Statistics, and Figures, CD-ROM Documentation, 17 pp., National Oceanographic Data Center, Silver Spring, MD, 2002.

Curry, W. B., Ostermann, D. R., Guptha, M. V. S., and Ittekkot, V.: Foraminiferal production and monsoonal upwelling in the Arabian Sea: evidence from sediment traps, in: Upwelling Systems: Evolution Since the Early Miocene, edited by: Summerhayes, C. P., Prell, W. L., and Emeis, K. C., pp. 93-106, The Geological Society, London, 1992.

Deuser, W. G.: Seasonal and interannual variations in deep-water particle fluxes in the Sargasso Sea and their relation to surface hydrography, Deep-Sea Res., 33, 225-246, 1986.

Deuser, W. G.: Seasonal variations in isotopic composition and deep-water fluxes of the tests of perennially abundant planktonic foraminifera of the Sargasso Sea: results from sediment-trap collections and their paleoceanographic significance, J. Foram. Res., 17, 14-27, 1987.

Deuser, W. G. and Ross, E. H.: Seasonally abundant planktonic foraminifera of the Sargasso Sea: succession, deep-water fluxes, isotopic compositions, and paleoceanographic implications, J. Foram. Res., 19, 268-293, 1989.

Deuser, W. G., Ross, E. H., Hemleben, C., and Spindler, M.: Seasonal changes in species composition, numbers, mass, size, and isotopic composition of planktonic foraminifera settling into the deep Sargasso Sea, Palaeogeogr. Palaeoclimatol. Palaeoecol., 33, 103-127, 1981.

Dittert, N. and Henrich, R.: Carbonate dissolution in the South Atlantic Ocean: evidence from ultrastructure breakdown in Globigerina bulloides, Deep-Sea Res. I, 47, 603-620, 2000.

Donner, B. and Wefer, G.: Flux and stable isotope composition of Neogloboquadrina pachyderma and other planktonic foraminifers in the Southern Ocean (Atlantic sector), Deep-Sea Res. I, 41, 1733-1743, 1994. 
Eguchi, N. O., Kawahata, H., and Taira, A.: Seasonal Response of Planktonic Foraminifera to Surface Ocean Condition: Sediment Trap Results from the Central North Pacific Ocean, J. Oceanogr., 55, 681-691, 1999.

Fairbanks, R. G. and Wiebe, P. H.: Foraminifera and Chlorophyll Maximum: Vertical Distribution, Seasonal Succession, and Paleoceanographic Significance, Science, 209, 1524-1526, 1980.

Fairbanks, R. G., Sverdlove, M., Free, R., Wiebe, P. H., and Bé, A. W. H.: Vertical distribution and isotopic fractionation of living planktonic foraminifera from the Panama Basin, Nature, 298, 841-844, 1982.

Fischer, G. and Wefer, G.: Long-term Observation of Particle Fluxes in the Eastern Atlantic: Seasonality, Changes of Flux with Depth and Comparison with the Sediment Record, in: The South Atlantic: Present and Past Circulation, edited by: Wefer, G., Berger, W. H., Siedler, G., and Webb, D. J., pp. 325-344, Springer-Verlag, Berlin Heidelberg, 1996.

Fischer, G., Donner, B., Ratmeyer, V., Davenport, R., and Wefer, G.: Distinct year-to-year particle flux variations off Cape Blanc during 1988-1991: Relation to $\delta^{18} \mathrm{O}$-deduced sea-surface temperatures and trade winds, J. Mar. Res., 54, 73-98, 1996.

Francois, R., Honjo, S., Krishfield, R., and Manganini, S.: Factors controlling the flux of organic carbon to the bathypelagic zone of the ocean, Global Biogeochem. Cycles, 16, 1087, doi:1010.1029/2001GB001722, 2002.

Freudenthal, T., Neuer, S., Meggers, H., Davenport, R., and Wefer, G.: Influence of lateral particle advection and organic matter degradation on sediment accumulation and stable nitrogen isotope ratios along a productivity gradient in the Canary Islands region, Mar. Geol., 177, 93-109, 2001.

Ganssen, G. M. and Kroon, D.: The isotopic signature of planktonic foraminifera from NE Atlantic surface sediments: implications for the reconstruction of past oceanic conditions, J. Geol. Soc., 157, 693-699, 2000.

Giraudeau, J., Bailey, G. W., and Pujol, C.: A high-resolution timeseries analyses of particle fluxes in the Northern Benguela coastal upwelling system: carbonate record of changes in biogenic production and particle transfer processes, Deep-Sea Res. II, 47, 1999-2028, 2000.

Guptha, M. V. S. and Mohan, R.: Seasonal variability of the vertical fluxes of Globigerina bulloides (d'Orbigny) in the northern Indian Ocean, Mitt. Geol.-Paläont. Inst. Univ. Hamburg, 79, 117, 1996.

Guptha, M. V. S., Curry, W. B., Ittekkot, V., and Muralinath, A. S.: Seasonal variation in the flux of planktic foraminifera: Sediment trap results from the Bay of Bengal, Northern Indian Ocean, J. Foram. Res., 27, 5-19, 1997.

Haake, B., Ittekkot, V., Rixen, T., Ramaswamy, V., Nair, R. R., and Curry, W. B.: Seasonality and interannual variability of particle fluxes to the deep Arabian Sea, Deep-Sea Res. I, 40, 1323-1344, 1993.

Hebbeln, D., Marchant, M., and Wefer, G.: Seasonal variations of the particle flux in the Peru-Chile current at $30^{\circ} \mathrm{S}$ under "normal" and El Niño conditions, Deep-Sea Res. II, 47, 2101-2128, 2000.

Hilbrecht, H.: Extant planktic foraminifera and the physical environment in the Atlantic and Indian Oceans, Mitteilungen aus dem Geologischen Institut der Eidgen. Technischen Hochschule und der Universität Zürich, Neue Folge, 300, 93 pp., 1996.
Ivanova, E., Schiebel, R., Singh, A. D., Schmiedl, G., Niebler, H.-S., and Hemleben, C.: Primary production in the Arabian Sea during the last 135000 years, Palaeogeogr. Palaeoclimatol. Palaeoecol., 197, 61-82, 2003.

Jensen, S.: Planktische Foraminiferen im Europäischen Nordmeer: Verbreitung und Vertikalfluß sowie ihre Entwicklung während der letzten 15000 Jahre, Berichte SFB 313, Univ. Kiel, 75, 105 pp., 1998.

Kincaid, E., Thunell, R. C., Le, J., Lange, C. B., Weinheimer, A. L., and Reid, F. M. H.: Planktonic foraminiferal fluxes in the Santa Barbara Basin: response to seasonal and interannual hydrographic changes, Deep-Sea Res. II, 47, 1157-1176, 2000.

King, A. L. and Howard, W. R.: Seasonality of foraminiferal flux in sediment traps at Chatham Rise, SW Pacific: implications for paleotemperature estimates, Deep-Sea Res. I, 48, 1687-1708, 2001.

King, A. L. and Howard, W. R.: Planktonic foraminiferal flux seasonality in Subantarctic sediment traps: A test for paleoclimate reconstructions, Paleoceanography, 18, 1019, doi:1010.1029/2002PA000839, 2003a.

King, A. L. and Howard, W. R.: Seasonal Subantarctic Planktonic Foraminiferal Flux Data, available from the IGBP PAGES/World Data Center for Paleoclimatology (http://www.ngdc.noaa.gov/ paleo), Data Contribution Series \# 2003-022., NOAA/NGDC Paleoclimatology Program, Boulder CO, USA, 2003 b.

Kohfeld, K. E., Fairbanks, R. G., Smith, S. L., and Walsh, I. D.: Neogloboquadrina pachyderma (sinistral coiling) as paleoceanographic tracers in polar oceans: Evidence from Northeast Water Polynya plankton tows, sediment traps, and surface sediments, Paleoceanography, 11, 679-699, 1996.

Kucera, M. and Darling, K. F.: Cryptic species of planktonic foraminifera: their effect on paleoceanographic reconstructions, Phil. Trans. R. Soc. Lond. A, 360, 695-718, 2002.

Kuroyanagi, A., Kawahata, H., Nishi, H., and Honda, M. C.: Seasonal changes in planktonic foraminifera in the northwestern North Pacific Ocean: sediment trap experiments from subarctic and subtropical gyres, Deep-Sea Res. II, 49, 5627-5645, 2002.

Laws, E. A., Falkowski, P. G., Smith Jr., W. O., Ducklow, H., and McCarthy, J. J.: Temperature effects on export production in the open ocean, Global Biogeochem. Cycles, 14, 1231-1246, 2000.

Le, J. and Thunell, R. C.: Modelling planktic foraminiferal assemblage changes and application to sea surface temperature estimation in the western equatorial Pacific Ocean, Mar. Micropal., 28, 211-229, 1996.

Lutz, M., Dunbar, R., and Caldeira, K.: Regional variability in the vertical flux of particulate organic carbon in the ocean interior, Global Biogeochem. Cycles, 16, 1037, doi:1010.1029/2000GB001383, 2002.

Lyle, M., Zahn, R., Prahl, F., Dymond, J., Collier, R., Pisias, N., and Suess, E.: Paleoproductivity and carbon burial across the California Current: The Multitracers Transect, $42^{\circ} \mathrm{N}$, Paleoceanography, 7, 251-272, 1992.

MacArthur, R. H.: Patterns of species diversity, Biol. Rev., 40, 510 533, 1965.

Marchant, M., Hebbeln, D., and Wefer, G.: Seasonal flux patterns of planktic foraminifera in the Peru-Chile Current, Deep-Sea Res. I, 45, 1161-1185, 1998.

Marchant, M., Hebbeln, D., Giglio, S., Coloma, C., and Gonzalez, H. E.: Seasonal and interannual variability in the flux of planktic 
foraminifera in the Humboldt Current System off central Chile (30 S), Deep-Sea Res. II, 51, 2441-2455, 2004.

Martin, J. H., Knauer, G. A., Karl, D. M., and Broenkow, W. W.: VERTEX: carbon cycling in the northeast Pacific, Deep-Sea Res., 34, 267-285, 1987.

Mohiuddin, M. M., Nishimura, A., Tanaka, Y., and Shimamoto, A.: Regional and interannual productivity of biogenic components and planktonic foraminiferal fluxes in the northwestern Pacific Basin, Mar. Micropal., 45, 57-82, 2002.

Mohiuddin, M. M., Nishimura, A., Tanaka, Y., and Shimamoto, A.: Seasonality of biogenic particle and planktonic foraminifera fluxes: response to hydrographic variability in the Kuroshio Extension, northwestern Pacific Ocean, Deep-Sea Res. I, 51, 16591683, 2004.

Moore, J. K., Doney, S. C., and Lindsay, K.: Upper ocean ecosystem dynamics and iron cycling in a global threedimensional model, Global Biogeochem. Cycles, 18, GB4028, doi:4010.1029/2004GB002220, 2004.

Moore, J. K., Doney, S. C., Kleypas, J. A., Glover, D. M., and Fung, I. Y.: An intermediate complexity marine ecosystem model for the global domain, Deep-Sea Res. II, 49, 403-462, 2001.

Morey, A. E., Mix, A. C., and Pisias, N. G.: Planktonic foraminiferal assemblages preserved in surface sediments correspond to multiple environment variables, Quat. Sci. Rev., 24, 925-950, 2005.

Mulitza, S., Wolff, T., Pätzold, J., Hale, W., and Wefer, G.: Temperature sensitivity of planktic foraminifera and its influence on the oxygen isotope record, Mar. Micropal., 33, 223-240, 1998.

Niebler, H.-S., Arz, H. W., Donner, B., Mulitza, S., Pätzold, J., and Wefer, G.: Sea surface temperatures in the equatorial and South Atlantic Ocean during the Last Glacial Maximum (23-19 ka), Paleoceanography, 18, 1069, doi:1010.1029/2003PA000902, 2003.

Nodder, S. D. and Northcote, L. C.: Episodic particulate fluxes at southern temperate mid-latitudes $\left(42-45^{\circ} \mathrm{S}\right)$ in the Subtropical Front region, east of New Zealand, Deep-Sea Res. I, 48, 833864,2001

Ortiz, J. D. and Mix, A. C.: The spatial distribution and seasonal succession of planktonic foraminifera in the California Current off Oregon, September 1987-September 1988, in: Upwelling Systems: Evolution Since the Early Miocene, edited by: Summerhayes, C. P., Prell, W. L., and Emeis, K. C., pp. 197-213, The Geological Society, London, 1992.

Ortiz, J. D., Mix, A. C., and Collier, R. W.: Environmental control of living symbiotic and asymbiotic foraminifera of the California Current, Paleoceanography, 10, 987-1009, 1995.

Ottens, J. J. and Nederbragt, A. J.: Planktic foraminiferal diversity as indicator of ocean environments, Mar. Micropal., 19, 13-28, 1992.

Peinert, R., Antia, A., Bauerfeind, E., v. Bodungen, B., Haupt, O., Krumbholz, M., Peeken, I., Ramseier, R. O., Voss, M., and Zeitzschel, B.: Particle Flux Variability in the Polar and Atlantic Biogeochemical Provinces of the Nordic Seas, in: The Northern North Atlantic: A Changing Environment, edited by: Schäfer, P., Ritzrau, W., Schlüter, M., and Thiede, J., pp. 53-68, Springer, Berlin, 2000.

Pflaumann, U., Sarnthein, M., Chapman, M., d'Abreu, L., Funnell, B., Huels, M., Kiefer, T., Maslin, M., Schulz, H., Swallow, J., van Kreveld, S., Vautravers, M., Vogelsang, E., and
Weinelt, M.: Glacial North Atlantic: Sea-surface conditions reconstructed by GLAMAP 2000, Paleoceanography, 18, 1065, doi:1010.1029/2002PA000774, 2003.

Prell, W. L., Martin, A., Cullen, J., and Trend, M.: The Brown University Foraminiferal Data Base, IGBP PAGES/World Data Center-A for Paleoclimatology, Data Contribution Series \# 1999027, NOAA/NGDC Paleoclimatology Program, Boulder CO, USA, 1999.

Reynolds, L. and Thunell, R. C.: Seasonal succession of planktonic foraminifera in the subpolar North Pacific, J. Foram. Res., 15, 282-301, 1985.

Reynolds, L. A. and Thunell, R. C.: Seasonal production and morphologic variation of Neogloboquadrina pachyderma (Ehrenberg) in the northeast Pacific, Micropal., 32, 1-18, 1986.

Reynolds, R. W. and Smith, T. M.: Improved global sea surface temperature analyses, J. Clim., 7, 929-948, 1994.

Sautter, L. R. and Thunell, R. C.: Seasonal succession of planktonic foraminifera: results from a four-year time-series sediment trap experiment in the northeast Pacific, J. Foram. Res., 19, 253-267, 1989.

Sautter, L. R. and Thunell, R. C.: Planktonic foraminiferal response to upwelling and seasonal hydrographic conditions: sediment trap results from San Pedro Basin, Southern California Bight, J. Foram. Res., 21, 347-363, 1991.

Schiebel, R.: Planktic foraminiferal sedimentation and the marine calcite budget, Global Biogeochem. Cycles, 16, 1065, doi:1010.1029/2001GB001459, 2002.

Schiebel, R., Waniek, J., Bork, M., and Hemleben, C.: Planktic foraminiferal production stimulated by chlorophyll redistribution and entrainment of nutrients, Deep-Sea Res. I, 48, 721-740, 2001.

Schlitzer, R.: Interactive analysis and visualization of geoscience data with Ocean Data View, Computers \& Geosciences, 28, 1211-1218, 2002a.

Schlitzer, R.: Carbon export fluxes in the Southern Ocean: results from inverse modeling and comparison with satellite-based estimates, Deep-Sea Res. II, 49, 1623-1644, 2002 b.

Scholten, J. C., Fietzke, J., Vogler, S., Rutgers van der Loeff, M. M., Mangini, A., Koeve, W., Waniek, J., Stoffers, P., Antia, A., and Kuss, J.: Trapping efficiencies of sediment traps from the deep Eastern North Atlantic: the ${ }^{230}$ Th calibration, Deep-Sea Res. II, 48, 2383-2408, 2001.

Schröder-Ritzrau, A., Andruleit, H., Jensen, S., Samtleben, C., Schäfer, P., Matthiessen, J., Hass, H. C., Kohly, A., and Thiede, J.: Distribution, Export and Alteration of Fossilizable Plankton in the Nordic Seas, in: The Northern North Atlantic: A Changing Environment, edited by: Schäfer, P., Ritzrau, W., Schlüter, M., and Thiede, J., pp. 81-104, Springer, Berlin, 2000.

Shannon, C. E. and Weaver, W.: The Mathematical Theory of Communication, 125 pp., University of Illinois Press, Urbana, 1949.

Stehli, F. G.: Paleontological technique for defining ancient ocean currents, Science, 148, 943-946, 1965.

Stehli, F. G., Douglas, R. G., and Newell, N. D.: Generation and maintenance of gradients in taxonomic diversity, Science, 164, 947-949, 1969.

Takahashi, K. and Bé, A. W. H.: Planktonic foraminifera: factors controlling sinking speed, Deep-Sea Res., 31, 1477-1500, 1984.

Tedesco, K. A. and Thunell, R. C.: Seasonal and interannual variations in planktonic foraminiferal flux and assemblage composi- 
tion in the Cariaco Basin, Venezuela, J. Foram. Res., 33, 192210,2003

Thompson, P. R., Bé, A. W. H., Duplessy, J. C., and Shackleton, N. J.: Disappearence of pink-pigmented Globigerinoides ruber at 120,000 yr BP in the Indian and Pacific Oceans, Nature, 280, 554-558, 1979.

Thunell, R. C. and Honjo, S.: Calcite dissolution and the modification of planktonic foraminiferal assemblages, Mar. Micropal., 6, 169-182, 1981.

Trull, T. W., Bray, S. G., Manganini, S. J., Honjo, S., and Francois, R.: Moored sediment trap measurements of carbon export in the Subantarctic and Polar Frontal Zones of the Southern Ocean, south of Australia, J. Geophys. Res., 106, 31 489-31 510, 2001.

Unger, D., Ittekkot, V., Schäfer, P., Tiemann, J., and Reschke, S.: Seasonality and interannual variability of particle fluxes to the deep Bay of Bengal: influence of riverine input and oceanographic processes, Deep-Sea Res. II, 50, 897-923, 2003.

Waelbroeck, C., Mulitza, S., Spero, H., Dokken, T., Kiefer, T., and Cortijo, E.: A global compilation of late Holocene planktonic foraminiferal $\delta^{18} \mathrm{O}$ : relationship between surface water temperature and $\delta^{18} \mathrm{O}$, Quat. Sci. Rev., 24, 853-868, 2005.

Watkins, J. M. and Mix, A. C.: Testing the effects of tropical temperature, productivity, and mixed-layer depth on foraminiferal transfer functions, Paleoceanography, 13, 96-105, 1998.

Watkins, J. M., Mix, A. C., and Wilson, J.: Living planktic foraminifera: tracers of circulation and productivity regimes in the central equatorial Pacific, Deep-Sea Res. II, 43, 1257-1282, 1996.
Wefer, G.: Particle Flux in the Ocean: Effects of Episodic Production, in: Productivity of the Ocean: Present and Past, edited by: Berger, W. H., Smetacek, V. S., and Wefer, G., pp. 139-154, John Wiley \& Sons, 1989.

Wefer, G., Berger, W. H., Bijma, J., and Fischer, G.: Clues to Ocean History: a Brief Overview of Proxies, in: Use of Proxies in $\mathrm{Pa}-$ leoceanography: Examples from the South Atlantic, edited by: Fischer, G. and Wefer, G., pp. 1-68, Springer-Verlag, Berlin Heidelberg, 1999.

Wong, C. S., Whitney, F. A., Crawford, D. W., Iseki, K., Matear, R. J., Johnson, W. K., Page, J. S., and Timothy, D.: Seasonal and interannual variability in particle fluxes of carbon, nitrogen and silicon from time series of sediment traps at Ocean Station P, 1982-1993: relationship to changes in subarctic primary productivity, Deep-Sea Res. II, 46, 2735-2760, 1999.

Yu, E.-F., Francois, R., Bacon, M. P., Honjo, S., Fleer, A. P., Manganini, S. J., Rutgers van der Loeff, M. M., and Ittekkot, V.: Trapping efficiency of bottom-tethered sediment traps estimated from the intercepted fluxes of ${ }^{230} \mathrm{Th}$ and ${ }^{231} \mathrm{~Pa}$, Deep-Sea Res. I, 48 , 865-889, 2001.

Žarić, S., Donner, B., Fischer, G., Mulitza, S., and Wefer, G.: Sensitivity of planktic foraminifera to sea surface temperature and export production as derived from sediment trap data, Mar. Micropal., 55, 75-105, 2005. 